\title{
Systemic Delivery of Allogenic Muscle Stem Cells Induces Long-Term Muscle Repair and Clinical Efficacy in Duchenne Muscular Dystrophy Dogs
}

\author{
Karl Rouger, ${ }^{\star \dagger}$ Thibaut Larcher, ${ }^{* \dagger}$ \\ Laurence Dubreil, ${ }^{* \dagger}$ Jack-Yves Deschamps, ${ }^{* \dagger}$ \\ Caroline Le Guiner, ${ }^{\neq \S}$ Gregory Jouvion, ${ }^{* \uparrow}$ \\ Bruno Delorme, ${ }^{\| * \star \dagger}$ Blandine Lieubeau, ${ }^{\text {} \neq \dagger}$ \\ Marine Carlus, ${ }^{* \dagger}$ Benoît Fornasari, ${ }^{, \dagger}$ \\ Marine Theret, ${ }^{* \dagger}$ Priscilla Orlando, ${ }^{\star \dagger}$ \\ Mireille Ledevin, ${ }^{\star \dagger}$ Céline Zuber, ${ }^{* \dagger}$ \\ Isabelle Leroux, ${ }^{* \dagger}$ Stéphane Deleau, ${ }^{* \dagger}$ \\ Lydie Guigand, ${ }^{* \dagger}$ Isabelle Testault, ${ }^{\S}$

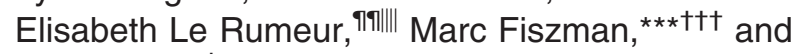 \\ Yan Chérel ${ }^{\star \dagger}$
}

From INRA," UMR 703 "Développement et Pathologie du Tissu Musculaire," Nantes; LUNAM Université, École Nationale Vétérinaire, Agro-alimentaire et de l'alimentation NantesAtlantique (Oniris), Nantes; INSERM, ${ }^{\ddagger}$ UMR 649, Nantes; the CHU Hotel Dieu, ${ }^{\S}$ Nantes; the Unité "Histopathologie Humaine et Modèles Animaux, "דा Département Infection et Epidémiologie, Institut Pasteur, Paris; INSERM, ESPRI-EA3855, Tours; the Faculté de Médecine, ${ }^{* *}$ Tours; MacoPharma, "† Tourcoing; INRA, the UMR 707 "Immunologie-Endocrinologie Cellulaire et Moléculaire," Nantes; the Centre Hospitalier Vétérinaire Atlantia, ${ }^{\text {SI }}$ Nantes; the CNRS, "वाा UMR 6026, Rennes; the Faculté de Médecine, ${ }^{|l|}$ Rennes; INSERM,*** U974, Paris; and the Institut de Myologie, IFR14, ${ }^{\text {tH }}$ Université Pierre et Marie Curie-Paris 6, UMR-S 974, CNRS UMR 7215, Paris, France

Duchenne muscular dystrophy (DMD) is a genetic progressive muscle disease resulting from the lack of dystrophin and without effective treatment. Adult stem cell populations have given new impetus to cellbased therapy of neuromuscular diseases. One of them, muscle-derived stem cells, isolated based on delayed adhesion properties, contributes to injured muscle repair. However, these data were collected in dystrophic mice that exhibit a relatively mild tissue phenotype and clinical features of DMD patients. Here, we characterized canine delayed adherent stem cells and investigated the efficacy of their systemic delivery in the clinically relevant DMD animal model to assess potential therapeutic applica- tion in humans. Delayed adherent stem cells, named MuStem cells (muscle stem cells), were isolated from healthy dog muscle using a preplating technique. In vitro, MuStem cells displayed a large expansion capacity, an ability to proliferate in suspension, and a multilineage differentiation potential. Phenotypically, they corresponded to early myogenic progenitors and uncommitted cells. When injected in immunosuppressed dystrophic dogs, they contributed to myofiber regeneration, satellite cell replenishment, and dystrophin expression. Importantly, their systemic delivery resulted in long-term dystrophin expression, muscle damage course limitation with an increased regeneration activity and an interstitial expansion restriction, and persisting stabilization of the dog's clinical status. These results demonstrate that MuStem cells could provide an attractive therapeutic avenue for DMD patients. (Am J Pathol 2011, 179:2501-2518; DOI: 10.1016/j.ajpath.2011.07.022)

Duchenne muscular dystrophy (DMD) is a progressive, fatal, X-linked recessive disorder of skeletal and cardiac muscles. It is the most common muscular dystrophy, affecting one in 3500 male births, ${ }^{1}$ and is characterized by the lack of dystrophin at the muscle fiber membrane. ${ }^{2,3}$ Dystrophin is the essential link between the subsarcolemmal cytoskeleton and the extracellular matrix. ${ }^{4,5}$ Disruption of this link results in fiber necrosis and progressive muscle weakness, which begins in early childhood. ${ }^{6}$

Supported by the Association Française contre les Myopathies (A.F.M.) Accepted for publication July 19, 2011

Supplemental material for this article can be found at http://ajp. amjpathol.org or at doi: 10.1016/j.ajpath.2011.07.022.

Address reprint requests to Karl Rouger, Ph.D.; correspondence to Karl Rouger, Ph.D., or Yan Chérel, Ph.D., INRA, UMR 703, École Nationale Vétérinaire, Agroalimentaire et de l'Alimentation Nantes-Atlantique (Oniris),RoutedeGachet,B.P.40706,44307Nantes,France.E-mail:karl.rouger@ nantes.inra.fr or yan.cherel@oniris-nantes.fr. 
Satellite cells represent unipotent myogenic precursors that are responsible for the postnatal growth and regenerative capacity of skeletal muscle. ${ }^{7}$ Based on this feature, they appeared as a natural candidate for DMD cell therapy. Several studies revealed that the transfer of myoblasts (ie, in vitro descendants of activated satellite cells) could restore dystrophin-expressing myofibers in X-linked muscular dystrophy (mdx) mice and DMD patients. $^{8-10}$ However, its effectiveness was hindered by poor cell survival, ${ }^{11,12}$ limited migration from the injection site, ${ }^{13,14}$ and immune rejection. ${ }^{15,16}$ Recently, interesting findings resulted from investigations on single-fiber transplantation into $\mathrm{mdx}$ or damaged muscle ${ }^{17}$ and injection of freshly isolated satellite cell subsets, ${ }^{18-20}$ which demonstrated a robust participation in muscle regeneration and satellite cell pool re-population, revealing that in vitro expansion highly contributes to the impaired engraftment capability of satellite cells. Based on their self-renewal and differentiation ability into different specialized cell types, including myogenic cells, the characterization of adult stem cells in a large number of tissues has led to new proposals of cell-based therapy approaches for genetic diseases such as DMD. These stem cells included side population (SP) cells, ${ }^{21-23} \mathrm{CD} 133^{+}$cells, ${ }^{24}$ mesoangioblasts (Mabs), ${ }^{25}$ mesenchymal stem cells, ${ }^{26-28}$ $\mathrm{PW} 1^{+} / \mathrm{Pax} 7^{-}$interstitial cells (PICs), ${ }^{29}$ and muscle-derived stem cells (MDSC). ${ }^{30}$ Intramuscular or intra-arterial injection of genetically corrected $\mathrm{CD} 133^{+}$cells, isolated from peripheral blood or muscles of DMD patients, resulted in significant recovery of muscle morphology, function, and dystrophin expression in scid/mdx mice. ${ }^{31}$ Wild-type mesoangioblast transplantation corrected the muscle dystrophic phenotype in $\alpha$-sarcoglycan null mice, ${ }^{32}$ and even mobility in the golden retriever muscular dystrophy (GRMD) dogs. ${ }^{33}$ MDSCs were isolated from mouse muscle, taking advantage of their delayed propensity to adhere on collagen-coated surfaces. ${ }^{30,34}$ When compared to myoblasts, these cells exhibited an improved ability to restore dystrophin ${ }^{+}$fibers following injection in mdx muscles. ${ }^{35}$ This property was further correlated to their capacity to escape rapid cell death, ${ }^{30,36}$ to proliferate after injection, ${ }^{30}$ and to escape immune rejection as a result of a low level of major histocompatibility complex class 1 expression. ${ }^{35}$ Among their advantages, their ability to self-renew efficiently and their multilineage capacity to differentiate was also reported. ${ }^{35,37,38}$ Lastly, MDSCs induced muscle regeneration after intravascular injection in mdx mice. ${ }^{39,40}$ More recently, studies confirmed that adult skeletal muscle contains nonadherent stem cells that are capable in vivo to contribute to the repair of injured muscle. ${ }^{41,42}$ Unfortunately, the potential of MDSCs isolated as nonadherent populations for cell therapy has only been tested in the mdx model, ${ }^{43}$ which exhibits limited clinical features and little or no endomysial fibrosis ${ }^{44}$ when compared to DMD patients.

In this report, we describe the characterization and the potential clinical use of a poorly adherent muscle-derived cell type that we called MuStem cells (muscle stem cells). These cells, isolated from dog skeletal muscle after serial replatings, were defined by an extensive proliferation ca- pacity associated with atypical division modalities by generating two morphologically distinct cells. They had an ex vivo multilineage differentiation potential even though they appeared to be committed to the myogenic lineage as evidenced by their ability to spontaneously differentiate into myotubes. In the GRMD dog, which represents the clinically relevant animal model for DMD, $, 4,46$ we showed that MuStem cells can regenerate muscle fibers, allowed dystrophin recovery, and relocated the satellite cell niche. When intra-arterially delivered, they contributed to a partial muscle tissue remodeling with an increase of the fiber regeneration activity and a limitation of the interstitial expansion. In addition, a striking and persistent clinical stabilization was reported for the transplanted GRMD dogs that were defined by an improved fatigability and a low intensity of limb stiffness and ankylosis. Altogether, these data reveal a potential therapeutic application for the MuStem cells.

\section{Materials and Methods}

\section{Animals}

GRMD dogs display an $A \rightarrow G$ mutation in the acceptor splice site of intron 6 of the dystrophin gene. Skipping of exon 7 disrupts the mRNA reading frame and results in premature termination of translation. ${ }^{47,48}$ Golden retriever crossbred dogs from a GRMD colony maintained in the Boisbonne Center for Gene Therapy of Oniris, NantesAtlantic College of Veterinary Medicine, Food Sciences and Engineering were studied. Affected dogs, which have progressive clinical dysfunction similar to that of DMD boys, as previously described, ${ }^{45,49}$ were initially identified based on PCR-based genotyping, and the pathology confirmed by a dramatic elevation of serum creatine kinase. ${ }^{50}$ The animal experiments were approved by the French National Institute for Agronomic Research and were performed according to the guidelines of the Institute. Investigations done in GRMD and healthy dogs are reported in Table 1.

\section{Isolation of Canine MuStem Cells}

Muscle-derived cells were obtained independently from seven 2-month-old healthy dogs from a pool of hind limb muscles (g/uteus medius and superficialis, semitendinosus, semimembranosus, biceps femoris, vastus lateralis and medialis, sartorius cranialis and caudalis, gracilis, tibialis cranialis, flexor digitorum superficialis, and gastrocnemius lateralis and medialis muscles), as previously described. ${ }^{51,52}$ Cells were placed in a growth medium [44\% DMEM (VWR, Strasbourg, France), 44\% M199 (VWR), 10\% fetal calf serum (Sigma, St. Louis, MO), 1\% penicillin/streptomycin/fungizon (Sigma), and 1\% L-glutamine (Sigma)], seeded at $10^{5} \mathrm{cells} / \mathrm{cm}^{2}$ on gelatin-coated flasks (Sigma), and submitted to an adaptation of the preplating technique. ${ }^{30}$ After 1 hour, floating cells were collected and replated on new flasks for 24 hours. This procedure was repeated daily for 4 days, after which time, floating cells were placed at $5.10^{3}$ to $10^{4}$ cells $/ \mathrm{cm}^{2}$ in new flasks and maintained for another 3 days 
Table 1. Summary of Investigations Performed on Dogs

\begin{tabular}{|c|c|c|c|c|c|}
\hline $\begin{array}{l}\text { Dog } \\
\text { number }\end{array}$ & $\begin{array}{l}\text { Genotypic } \\
\text { status }\end{array}$ & $\begin{array}{l}\text { Age (onset of } \\
\text { experiment) }\end{array}$ & $\begin{array}{l}\text { Specific } \\
\text { experiment }\end{array}$ & $\begin{array}{c}\text { Nature of } \\
\text { injected cells }\end{array}$ & $\begin{array}{l}\text { Immune } \\
\text { suppression }\end{array}$ \\
\hline 1 to 7 & WT & 2-month-old & $\begin{array}{l}\text { MuStem cell and } \\
\text { myoblast } \\
\text { isolation }\end{array}$ & & None \\
\hline 8 & GRMD & 2.5-month-old & $\begin{array}{l}\text { IM injection, tissue } \\
\text { distribution }\end{array}$ & $\begin{array}{l}\text { nls-lacZ MuStem cells } \\
\text { and myoblasts }\end{array}$ & Cyс A, MMF \\
\hline 9 to 11 & GRMD & 8-month-old & $\begin{array}{l}\text { IM injection, tissue } \\
\text { distribution }\end{array}$ & nls-lacZ MuStem cells & Cyс A, MMF \\
\hline 12,13 & WT & 2.5-month-old & $\begin{array}{l}\text { IM injection, tissue } \\
\text { distribution }\end{array}$ & nls-lacZ MuStem cells & Cус A, MMF \\
\hline 14,15 & GRMD & 7-month-old & $\begin{array}{l}\text { IF injection, tissue } \\
\text { distribution }\end{array}$ & nls-lacZ MuStem cells & Cус A, MMF \\
\hline 16 & GRMD & 2-month-old & $\begin{array}{l}\text { IF injection, clinical } \\
\text { follow-up }\end{array}$ & MuStem cells & Cyс A, MMF \\
\hline 17 & GRMD & 3-month-old & $\begin{array}{l}\text { IF injection, clinical } \\
\text { follow-up }\end{array}$ & MuStem cells & Cус A, MMF \\
\hline 18 & GRMD & 4-month-old & $\begin{array}{l}\text { IF injection, clinical } \\
\text { follow-up }\end{array}$ & MuStem cells & Cyc A, MMF \\
\hline 19 & GRMD & 1.5-month-old & Clinical follow-up & & Cус A, MMF \\
\hline 20 & GRMD & 3-month-old & Clinical follow-up & & Cyc A, Pred \\
\hline 21 & GRMD & 3-month-old & Clinical follow-up & & Cyc A, Aza \\
\hline 22,23 & GRMD & 3-month-old & Clinical follow-up & & None \\
\hline 24 & GRMD & 1-month-old & Clinical follow-up & & None \\
\hline
\end{tabular}

A sequential number defines different dogs. Their age at the onset of the experiments and genotypic status are mentioned (GRMD or WT, wild-type) Nature of injected cells and mode of delivery are indicated (IM, intra-muscular injection; IF, intra-femoral injection).

Aza, azathioprine; Cyc A, cyclosporin A; MMF, mycophenolate mofetil; Pred, prednisolone.

without medium change. Adherent cells were then expanded in medium (37\% DMEM, $2.5 \mathrm{~g} / \mathrm{L}$ glucose, 37\% M199, 10\% fetal calf serum, 10\% horse serum, $1 \%$ penicillin/streptomycin/fungizon, $20 \mathrm{mg} / \mathrm{mL}$ insulin) containing human recombinant factors $[10 \mathrm{ng} / \mathrm{mL}$ basic fibroblast growth factor, $50 \mathrm{ng} / \mathrm{mL}$ epidermal growth factor, and $25 \mathrm{ng} / \mathrm{mL}$ stem cell factor (PromoCell, Heidelberg, Germany)]. Myoblasts, corresponding to a pool of cells collected from preplatings 2 to 4 , were expanded in growth medium.

\section{In Vitro Proliferation Analysis}

Clonal cultures were obtained by limiting dilution and were performed for MuStem cells and myoblasts that served as a control. After 8 days, clones were fixed in $4 \%$ paraformaldehyde (PFA) and incubated 1 hour at room temperature with mouse monoclonal antibody (mAb) against desmin (1:50; Dako, Glostrup, Denmark) or Pax7 [1:10; Developmental Studies Hybridoma Bank (DSHB), lowa City, IA] in combination with biotinylated goat antimouse Ig (30 minutes, room temperature; Dako) that was revealed by peroxidase-diaminobenzidine staining (Dako). Proliferation was determined by counting the nuclei number in each desmin ${ }^{+}$or $\mathrm{Pax}^{+}$single cell-derived colony stained with Giemsa. In addition, population doubling level was examined on four MuStem cell-derived primary cultures at each passage as previously described. ${ }^{53}$

\section{Differentiation Potential Assay}

To assess the differentiation potential of MuStem cells, primary bulk cultures (ie, culture of all single cells) were maintained in standard growth medium until confluence, after which they were incubated in specific cell-type differentiation media. For myogenic differentiation, 10\% fetal calf serum was replaced by $2 \%$ horse serum in medium. After 2 days, differentiation was assessed on the basis of cell morphology and the developmental isoform of myosin heavy chain (MyHCd) expression. Cultures were fixed in 4\% PFA, treated with $0.5 \%$ Triton X-100/20\% (w/v) goat serum in PBS, and incubated 1 hour with human MyHCd mAb (Novocastra Laboratories, Newcastle on Tyne, UK). Immunolabeling was revealed as described above. Osteogenic and adipogenic differentiation were induced and characterized as described previously. ${ }^{54}$

\section{Flow Cytometry and Immunocytochemistry}

For flow cytometry, four MuStem cell samples and three myoblast samples were resuspended in PBS/5\% dog serum and incubated (30 minutes, $4^{\circ} \mathrm{C}$ ) with fluorochrome-conjugated antibodies $(\mathrm{Ab})$ to the following antigens: CD14, CD34, CD44, CD49d, CD62L, CD90 (BD Biosciences, Franklin Lakes, NJ), CD5, CD21, CD45 (AbD Serotec, Düsseldorf, Germany), CD56 (Dako), Bcrp1 (eBiosciences, Montrouge, France). CD11b (AbD Serotec) labeling was performed according to a classic two-step protocol using fluorochrome-conjugated secondary $\mathrm{Ab}$ (AbD Serotec). To validate labelings, preliminary experiments were conducted on canine peripheral blood cells and bone marrow cells. Surface antigens were evaluated in at least 200,000 viable cells using a FACSAria flow cytometer and analyzed using Diva v6 1.2 software (BD Biosciences). Isotype-matched Ab were used as negative controls for gating and analyses. For 
cytological immunolabelings on cytospin preparations and Lab-Tek chamber slides (Nalge Nunc International, Rochester, NY), three MuStem cell samples and three myoblast samples were fixed in 2\% PFA (10 minutes) and treated with $0.5 \%$ triton $\mathrm{X}-100$ (30 minutes), except for CD31 Ab. After incubation (1 hour, room temperature) in blocking buffer (2\% goat serum in PBS), cells were incubated with Ab: CD31 (1:50; Dako), Pax7 (1:25; DSHB), Myf5 (1:500; Santa Cruz Biotechnology, Santa Cruz, CA), MyoD (1:25, Dako), desmin (1:50; Dako), and $\beta 1$-integrin (1:50; DSHB) (1 hour, room temperature for CD31, Pax7, Myf5; overnight, $4^{\circ} \mathrm{C}$ for MyoD, desmin, $\beta 1$-integrin). The slides were incubated with Alexa fluor 488 or 555 secondary Ab (1:500; Invitrogen, Carlsbad, CA) (1 hour, room temperature) and DRAQ5 red fluorescent cell-permeable DNA probe (Biostatus, Loughborough, UK) (15 minutes, room temperature). More than 550 cells were counted per sample for cytospin preparations, whereas at least 118 round cells and 214 spindle-shaped cells were considered for Lab-Tek chamber slides. Data were presented as the mean \pm SD of independent experiments.

\section{Retroviral Infection}

Recombinant nuclear-localizing site n/s-lacZ retroviral particles were used to label MuStem cells and myoblasts with a nuclear lac $Z$ expression, as previously described. ${ }^{55} \mathrm{~A}$ control of retroviral infection efficiency was performed by determining the percentage of lac $Z^{+}$nuclei (always more than 85\%).

\section{Immunosuppressive Treatment}

GRMD dogs were immunosuppressed with $32 \mathrm{mg} / \mathrm{kg} /$ day of oral cyclosporine (Neoral; Novartis, Rueil-Malmaison, France) in combination with $6 \mathrm{mg} / \mathrm{kg}$ mycophenolate mofetil (CellCept; Roche, Paris, France). Ten mg/kg of ketoconazole (Nizoral; Janseen-Cilag, Issy-les-Moulineaux, France) was also added daily to decrease cyclosporine catabolism. Blood levels of cyclosporine were controlled twice a week and maintained between 250 and $300 \mathrm{ng} / \mathrm{mL}$. The immunosuppressive regimen was started 1 week before cell administration and maintained throughout the experiment. One mock-treated GRMD dog received the same immunosuppressive regimen while the second received $2 \mathrm{mg} / \mathrm{kg} /$ day prednisolone (Megasolone; Merial, Lyon, France) in place of mycophenolate mofetil.

\section{Intramuscular Injection}

Gluteus superficialis muscle, triceps brachii muscle, and semitendinosus muscle of a 2.5-month-old GRMD dog (\#8 in Table 2) were surgically exposed and injected with $2 \cdot 10^{6}$ viable $n / s-l a c Z$-transduced cells suspended in 250 $\mu \mathrm{L}$ of $0.9 \% \mathrm{NaCl} / 2.5 \%$ homologous serum: the left muscles received MuStem cells, whereas the right counterparts were injected with myoblasts. Alternatively, MuStem cells were injected in the triceps brachii muscle of three 8-month-old GRMD dogs (\#9 to \#11) and in the Biceps femoris muscle of two 2.5-month-old dogs (\#12, \#13). Four weeks later, injected muscles were biopsied.

\section{Systemic Delivery Procedure}

MuStem cells were suspended at $2 \cdot 10^{6}$ cells $/ \mathrm{mL}$ in $0.9 \%$ $\mathrm{NaCl} / 2.5 \%$ homologous serum $/ 50 \mathrm{U} / \mathrm{mL}$ heparin. A 2-cmlong segment of the femoral artery was surgically exposed through an inguinal incision and a 26-gauge catheter $(1.9 \mathrm{~cm}$ long; Terumo, Leuven, Belgium) was totally inserted in a retrograde direction. Consequently, its extremity was not advanced as deep as the aortoiliac bifurcation, and so cells were consistently injected unilaterally in the left femoral artery. Five injections of $1 \cdot 10^{7}$ MuStem cells $/ \mathrm{kg}$ and three injections of $2 \cdot 10^{7} \mathrm{n} / \mathrm{s}$-lacZ-transduced MuStem cells/kg were performed respectively in three (\#16 to \#18) and two (\#14, \#15) GRMD dogs at 2- to 4-week intervals, using laminar flow at a rate of $5 \mathrm{~mL} / \mathrm{min}$. Intra-arterial injections were always performed on GRMD dogs aged from 2 to 6 months old.

\section{Muscle Biopsy}

Biopsies of n/s-lacZ-transduced MuStem cell-injected muscles were divided into two parts for immunohistochemistry analysis (cryopreserved) and lacZ histochemistry (paraffin-embedded) using an in toto enzymatic technique, as previously described. ${ }^{56}$ Small fragments $\left(0.5 \mathrm{~cm}^{3}\right)$ of biceps femoris and/or tibialis cranialis muscle were collected from healthy dogs, mock-immunosuppressed GRMD dogs, and MuStem cell-injected GRMD dogs at various time points and divided into two parts for histological and molecular analysis. Semitendinosus and gracilis muscle biopsies were done 8 weeks after the n/s-lacZ-transduced MuStem cell systemic administration and processed as described above for n/s-lacZ-transduced MuStem cell-injected muscles.

\section{RT-PCR Analysis}

Total RNA was isolated with the TRIzol method (Invitrogen) and transcribed into cDNA using a M-MLV (Moloney Murine Leukemia Virus) Reverse Transcriptase (Invitrogen) $\left(1\right.$ hour, $\left.37^{\circ} \mathrm{C}\right)$ and a primer specific for the canine dystrophin mRNA (5'-GTGATGATGTTGTTCTGATACTCCAGCCAG-3'). Because the first AG in exon 7 acts as an alternate acceptor splice site and generates a rare dystrophin transcript including exon 7 in which only the first five bases are missing, ${ }^{57}$ a reaction specific for the wildtype canine dystrophin mRNA was performed using Ampli Tag Gold DNA polymerase (Ambion, Foster City, CA) with primers at the junction of exon 6/7 (5'-TCTCATCCACAGTCATAGGCCAG-3') and in exon 9 (5'-AATGCTGTGAAGGAAGTGGGCTC-3'). The PCR cycle consisted of: initial denaturation $\left(5\right.$ minutes, $95^{\circ} \mathrm{C}$ ) followed by $40 \mathrm{cy}$ cles (30 seconds, $94^{\circ} \mathrm{C} ; 30$ seconds, $63^{\circ} \mathrm{C} ; 1$ minute, $72^{\circ} \mathrm{C}$ ), and a final extension ( 10 minutes, $72^{\circ} \mathrm{C}$ ). An internal control reaction was performed to detect the sequence of exon 1 to exon 3 (5'-GGGATCACTCACTTTCCCCTTAC-3' $/ 5^{\prime}$-AAAGGTCTAGGAGGCGTCTCCC-3'). The PCR cycle was: initial denaturation $\left(5\right.$ minutes, $95^{\circ} \mathrm{C}$ ) 
Table 2. Distribution of $l a c Z^{+}$Nuclei in GRMD Dog Muscles after MuStem Cell Delivery

\begin{tabular}{|c|c|c|c|c|c|}
\hline \multirow[b]{2}{*}{$\begin{array}{l}\text { Dog } \\
\text { number }\end{array}$} & \multirow[b]{2}{*}{ Muscle } & \multirow[b]{2}{*}{$\begin{array}{l}\text { Number of } \\
\text { lac } Z^{+} \text {nuclei }\end{array}$} & \multicolumn{3}{|c|}{ Tissue localization of lac $Z^{+}$nuclei } \\
\hline & & & $\begin{array}{l}\text { Subbasal } \\
\text { position }\end{array}$ & $\begin{array}{l}\text { Centronuclear } \\
\text { position }\end{array}$ & $\begin{array}{l}\text { Interstitial } \\
\text { tissue }\end{array}$ \\
\hline \multirow[t]{3}{*}{8} & Gluteus superficialis & 3205 & $2445(76.3 \%)$ & 320 (10.0\%) & $440(13.7 \%)$ \\
\hline & Triceps brachii & 2999 & $1865(62.2 \%)$ & $693(23.1 \%)$ & $441(14.7 \%)$ \\
\hline & Semitendinosus & 2540 & $1952(76.9 \%)$ & $351(13.8 \%)$ & $237(9.3 \%)$ \\
\hline Total & & 8744 & 6262 & 1364 & 1118 \\
\hline Percentage & & & $71.6 \%$ & $15.6 \%$ & $12.8 \%$ \\
\hline $\begin{array}{l}95 \% \text { confidence } \\
\text { interval }\end{array}$ & & & $70.7-72.6$ & $14.9-16.4$ & $12.1-13.5$ \\
\hline 9 & Triceps brachii & 549 & $510(92.9 \%)$ & 38 (6.9\%) & $1(0.2 \%)$ \\
\hline 10 & Triceps brachii & 641 & $598(93.3 \%)$ & $42(6.5 \%)$ & $1(0.2 \%)$ \\
\hline 11 & Triceps brachii & 536 & $503(93.8 \%)$ & $32(6.0 \%)$ & $1(0.2 \%)$ \\
\hline Total & & 1726 & 1611 & 112 & 3 \\
\hline Percentage & & & $93.3 \%$ & $6.5 \%$ & $0.17 \%$ \\
\hline $\begin{array}{l}95 \% \text { confidence } \\
\text { interval }\end{array}$ & & & $92.2-94.5$ & $5.3-7.7$ & $0-0.4$ \\
\hline
\end{tabular}

\begin{tabular}{|c|c|c|c|c|c|}
\hline \multirow[b]{2}{*}{$\begin{array}{c}\text { Dog } \\
\text { number }\end{array}$} & \multirow[b]{2}{*}{ Muscle } & \multirow[b]{2}{*}{$\begin{array}{l}\text { Number of } \\
\text { lac } Z^{+} \text {nuclei }\end{array}$} & \multicolumn{3}{|c|}{ Tissue localization of lac $Z^{+}$nuclei } \\
\hline & & & $\begin{array}{l}\text { Below plasma } \\
\text { membrane }\end{array}$ & $\begin{array}{l}\text { Above basal } \\
\text { membrane }\end{array}$ & $\begin{array}{l}\text { Between both } \\
\text { membrane }\end{array}$ \\
\hline 12 & Biceps femoris & 326 & $238(73.0 \%)$ & $35(10.7 \%)$ & 53 (16.3\%) \\
\hline 13 & Biceps femoris & 314 & $217(69.1 \%)$ & $43(13.7 \%)$ & $54(17.2 \%)$ \\
\hline \multirow{3}{*}{$\begin{array}{l}\text { Total } \\
\text { Percentage } \\
\text { 95\% confidence } \\
\quad \text { interval }\end{array}$} & & 640 & 455 & 78 & 107 \\
\hline & & & $71.1 \%$ & $12.2 \%$ & $16.7 \%$ \\
\hline & & & $67.6-74.6$ & $9.7-14.7$ & $13.8-19.6$ \\
\hline & & & \multicolumn{3}{|c|}{ Tissue localization of lac $Z^{+}$nuclei } \\
\hline $\begin{array}{l}\text { Dog } \\
\text { number }\end{array}$ & Muscle & $\begin{array}{l}\text { Number of } \\
\text { lac } Z^{+} \text {nuclei }\end{array}$ & $\begin{array}{l}\text { Subbasal } \\
\text { position }\end{array}$ & $\begin{array}{l}\text { Centronuclear } \\
\text { position }\end{array}$ & $\begin{array}{l}\text { Interstitial } \\
\text { tissue }\end{array}$ \\
\hline \multirow{2}{*}{14} & Semitendinosus & 127 & $100(78.7 \%)$ & $0(0 \%)$ & $27(21.3 \%)$ \\
\hline & Gracilis & 239 & $191(79.9 \%)$ & $0(0 \%)$ & $48(20.1 \%)$ \\
\hline \multirow[t]{2}{*}{15} & Semitendinosus & 104 & $67(64.4 \%)$ & $14(13.5 \%)$ & $23(22.1 \%)$ \\
\hline & Gracilis & 251 & $249(99.2 \%)$ & $0(0 \%)$ & $2(0.8 \%)$ \\
\hline Total & & 721 & 607 & 14 & 100 \\
\hline Percentage & & & $84.2 \%$ & $1.9 \%$ & $13.9 \%$ \\
\hline $\begin{array}{l}95 \% \text { confidence } \\
\text { interval }\end{array}$ & & & 81.5-86.9 & $0.9-2.9$ & $11.4-16.4$ \\
\hline
\end{tabular}

Tissue localization of lac $Z^{+}$nuclei was determined on several skeletal muscles of eight dogs, 4 weeks after MuStem cell injection. Six dogs received intramuscular injection (\#8 to \#13), whereas two others received intra-arterial delivery (\#14 and \#15).

followed by 40 cycles (30 seconds, $94^{\circ} \mathrm{C} ; 30$ seconds, $60^{\circ} \mathrm{C} ; 1$ minute, $72^{\circ} \mathrm{C}$ ), and a final extension ( 10 minutes, $72^{\circ} \mathrm{C}$ ). The reactions generated, respectively, a 455-bp amplicon and a 374-bp amplicon that were analyzed using agarose gel electrophoresis and ethidium bromide staining.

\section{Immunohistochemistry}

Transverse cryosections were incubated (overnight, $4^{\circ} \mathrm{C}$ ) with the primary $\mathrm{Ab}$ against $\beta$-galactosidase (1:3000; Chemicon, Euromedex, Mundolsheim, France), dystrophin (1:50; Novocastra; 1:50; Santa Cruz Biotechnology), utrophin (1:50; Novocastra), $\beta$-sarcoglycan (1:50; Novocastra), $\gamma$-sarcoglycan (1:50; Novocastra), $\beta$-dystroglycan (1:50; Novocastra), MyHCd (1:100; Novocastra), Pax7 (1:10; DSHB), laminin (1:1000; Sigma). For triple immunolabelings, Alexa fluor $(488,555$, or 633$)$ conjugated goat anti-mouse or goat anti-rabbit IgG (1:300; Invitrogen) (1 hour, room temperature) were used. For
CD4 (1:400; Serotec, Kidlington, UK), CD8 (1:400; Serotec), CD11b (1:300; Serotec), and CD79 (1:500; Dako), sections were fixed in acetone and $4 \%$ PFA, respectively, treated with $10 \% \mathrm{H}_{2} \mathrm{O}_{2}$ in methanol (10 minutes, room temperature), blocked with buffer (0.2\% PBS/Tween, $20 \%$ goat serum) (30 minutes, room temperature), and incubated (overnight, $4^{\circ} \mathrm{C}$ ) with the primary Ab. The sections were incubated with biotinylated goat anti-mouse (1:300; Dako) or goat anti-rat IgG (1:400; Invitrogen) (1 hour, room temperature) and streptavidin horseradish peroxidase (15 minutes, room temperature) that was revealed using 3,3'-diaminobenzidine (DAB) chromogen (10 minutes, room temperature). For localization of lac $Z^{+}$nuclei, paraffin sections previously submitted to enzymatic technique were treated with $0.1 \%$ trypsin (10 minutes, room temperature), $3 \% \mathrm{H}_{2} \mathrm{O}_{2}$ in methanol (10 minutes, room temperature), and with blocking buffer $(0.2 \%$ PBS/Tween, $5 \%$ goat serum; 30 minutes, room temperature). Sections were incubated with rabbit polyclonal $\mathrm{Ab}$ against dystrophin (1:25; Chemicon) 
(1 hour, room temperature) followed by biotinylated goat anti-rabbit (1:300; Vector Laboratories, Burlingame, CA) (30 minutes, room temperature) and streptavidin horseradish peroxidase (30 minutes, room temperature) that was revealed using DAB chromogen (15 minutes, room temperature). Sections were then incubated with mouse mAb against laminin (1:500; DSHB) (1 hour, room temperature) followed by biotinylated goat anti-mouse (1:300; Vector Laboratories) (30 minutes, room temperature) and streptavidin alkaline phosphatase (30 minutes, room temperature) that was revealed using fuchsin (15 minutes, room temperature). Immunofluorescence labelings were observed with a laser scanning confocal microscope (Nikon C1; Champigny, France). For dystrophin labeling, all acquisitions were performed with the same signal amplification resulting from identical detector gain value. With this value, no fluorescent signal was detected on control slides corresponding to cell-injected GRMD dog muscle sections incubated with immunoglobulin isotype control or in GRMD dog muscle sections incubated with dystrophin mAb. Blinded examination of the dystrophin labeling was always performed by at least two persons. To determine the proportion of dystrophin $^{+}$fibers, a total of 1000 laminin $^{+}$fibers were counted in separate sections from the biceps femoris muscle and tibialis cranialis muscle of MuStem cellinjected GRMD dogs $(n=2)$, and the percentage of fibers expressing dystrophin was determined.

\section{Histomorphometry}

Biceps femoris muscle samples of 7-month-old dogs (healthy, mock-immunosuppressed GRMD and MuStem cell-injected GRMD; $n=3$ per group) were processed in $8-\mu \mathrm{m}$-thick cryosections. Morphometric analysis was done using a digital camera (Nikon DXM 1200; Nikon Instruments, Badhoevedorp, the Netherlands) combined with image-analysis software (NIS; Nikon). Microscopic fields were randomly selected on hematoxylin-eosin-safranin-stained sections using intermediate magnification to observe at least 100 fibers ( $160 \pm 31$ per sample). The minimal Ferret diameter was used to determine fiber size distribution. Necrotic muscle fibers were determined on 10 high-magnification fields randomly selected on Gomori trichrome-stained sections and the percentage of necrotic fibers was calculated considering the total number of fibers. Fibrosis was determined as the ratio of areas rich in collagen on the total muscle area in an overall cross section, as described elsewhere. ${ }^{58}$ Endomysial space thickness was measured among two high-magnification fields using Gomori trichrome staining. Foci of calcification, revealed by Alizarin Red staining, were measured on 10 low-magnification fields. To determine the percentage of $\mathrm{MyHCd}^{+}$fibers, at least 500 fibers $(640 \pm 84)$ were numbered on two randomly selected microscopic fields. For each measurement, reproducibility was above $92 \%$.

\section{Immunoblotting}

Membrane-enriched fraction (KCL-washed microsomes) was isolated from muscle biopsies by ultracentrifugation at $4^{\circ} \mathrm{C}$, as previously described. ${ }^{59}$ Protein concentration was determined using bicinchoninic acid protein assay (Pierce, Rockford, IL) with bovine serum albumin as standard. Proteins were separated by $6 \%$ SDS-polyacrylamide gel electrophoresis (PAGE) and transferred to a protran BA83 nitrocellulose membrane (Whatman, Maidstone, UK) by electroblotting with a Mini Trans-Blot Cell (Bio-Rad, Marne-la-Coquette, France). The membranes were blocked (overnight, $4^{\circ} \mathrm{C}$ ) with Tris-buffered saline [20 mmol/L Tris- $\mathrm{HCl}, 500 \mathrm{mmol} / \mathrm{L} \mathrm{NaCl}(\mathrm{pH} 7.5)] / 0.1 \%$ Tween 20/5\% nonfat dry milk and incubated (3 hours, room temperature) with dystrophin $\mathrm{mAb}$ (1:20, DYS1; Novocastra) or with myosin mAb (1:2000, MF20; DSHB) in blocking buffer. After washes in TBS, the membranes were incubated ( 1 hour, room temperature) with Alexa Fluor 680 conjugated goat anti-mouse IgG (1:10,000 in blocking buffer; Invitrogen). The fluorescence emitted by the protein bands was monitored using the Odyssey Infrared Imaging system (Li-COR Biosciences, Lincoln, NE).

\section{Clinical Follow-Up}

A clinical evaluation was performed weekly by the same D.V.M. observer on GRMD dogs $(n=3)$, mock-immunosuppressed GRMD dogs $(n=2)$, and MuStem cellinjected ones $(n=3)$, using an extended version of a published grid. ${ }^{60}$ The observer always followed the same protocol on animals walking around in a quiet room, and scoring items were always observed in the same order. For practical reasons, it was not possible to perform this evaluation blindly. In addition to the previously described 11 locomotion criteria, 6 items related to the general health status (dysphagia, ptyalism, hypertrophy of the base of the tongue, mouth opening, global activity, and breathing) were added. Each item was scored from 0 to 2, with 0 corresponding to a normal appearance, 1 to an intermediate phenotype, and 2 to a severe alteration. Data related to validation of the clinical evaluation method were already published $^{61}$ and available at http://theses.vet-alfort.fr/ telecharger.php?id=1015. The clinical score was expressed as the complement of a healthy dog score of $100 \%$ and a tendency curve (mobile means order 3) was built to represent the score evolution. Serum levels of creatine kinase and aspartate aminotransferase were measured weekly from 1 week before the first MuStem cell administration.

\section{Statistics}

All data were reported as means \pm SD. Mean fiber size and endomysial thickness were compared among different dog groups with analysis of variance followed by Fisher PLSD tests and creatine kinase levels with analysis of covariance, using StatView software (Brain Power, Calabasas, CA). Means were compared using an unpaired Student's t-test for the size of colonies between myoblasts and MuStem cells. Percentages of $\mathrm{MyHC}^{+}$ fibers were compared between MuStem cell-injected and mock-immunosuppressed GRMD dogs using a Mann-Whit- 
ney test with a two-tailed $P$ value. A value of $P<0.05$ was considered to be statistically significant.

\section{Results \\ MuStem Cells Exhibit High Proliferation Rate and Atypical Division Pattern}

When healthy dog skeletal muscle-derived cells were grown in vitro, a marginal fraction of nonadherent cells (representing $1.2 \% \pm 0.5 \%$ of total extracted cells; $n=7$ ) was isolated among myoblasts that firmly adhered to the coated plastic. These refringent rounded cells, named MuStem cells, were isolated on day 4 using serial platings; they required three additional days to anchor slightly to a collagen matrix, and initially grew by forming microspheroid colonies. The colonies rapidly became composed of a large number of superposed cells and scattered to generate a majority of spindle-shaped cells while others remained round (Figure 1A). These two cell phenotypes were maintained after several passages (Figure 1B), with some round cells that divided into one round cell and one spindle-shaped myoblast (Figure 1B). Round cells represented $17.8 \% \pm 1.1 \%, 10.2 \% \pm 1.9 \%$, and $10.6 \% \pm 0.8 \%$ of all cells at passage 1 (P1), P3, and P6, respectively ( $n=3500$ cells counted per passage). Originally, when cultured under nonadherent condition, MuStem cells proliferated as clusters of rounded cells termed myospheres containing many hundreds of cells (Figure 1C). Myospheres maintained the ability to spontaneously give rise to a mixed population of spindleshaped and round cells when replaced in an adherent condition (Figure 1C), demonstrating that MuStem cells adopt distinct behavior depending on the environment.

Clonal culture analyses showed that MuStem cells displayed clonogenic ability (Figure 1D). The average nucleus number per colony was $360 \pm 325$ compared to $231 \pm 265$ for myoblasts after 8 days ( $n=161$ clones), indicating that MuStem cells have a higher proliferation capacity than myoblasts $(P<0.05)$. In addition, we showed that MuStem cells are able to make $20.4 \pm 1.6$ population-doubling levels in 36 days of primary culture without reaching senescence. Importantly, as described for the original primary cultures, presence of both spindleshaped cells and round ones was detected in MuStem cell-derived colonies (Figure 1D), which demonstrated atypical division modalities for the MuStem cells.

\section{MuStem Cells Are Mainly Early Myogenic Progenitors with Oligopotency}

Fluorescence-activated cell sorting analysis and immunocytochemistry on cytospin preparation showed that $81 \% \pm 4 \%$ and $59 \% \pm 10 \%$ of the MuStem cells were positive for the satellite cell markers CD56 and $\beta 1$-integrin, respectively; $46 \% \pm 4 \%$ and $42 \% \pm 3 \%$ of the cells expressed the paired box transcription factor Pax7 that is required for specification of myogenic cells and the early myogenic regulatory factor Myf5, respectively. Expression of the key regulator of myoblast differentiation MyoD and the intermediate filament desmin was detected in
$49 \% \pm 2 \%$ and $34 \% \pm 4 \%$, respectively (Figure $2 \mathrm{~A}$ and data not shown). MuStem cells were uniformly negative for surface markers CD45 and CD34, typically expressed by hematopoietic and endothelial lineage cells, and for CD49d, CD62L, and Bcrp1. Adhesion molecule CD44 was detected in all MuStem cells, whereas $2 \%$ to $7.4 \%$ of cells consistently expressed the cell-surface glycoprotein Thy-1/ CD90 (Figure 2A). Endothelial marker CD31 and blood lineage markers such as CD5, CD11b, CD14, and CD21 were not expressed by MuStem cells or myoblasts (data not shown). In addition, immunofluorescence analysis in fixed cultured cells showed that Pax7, Myf5, and MyoD were expressed by $73 \% \pm 18 \%, 45 \% \pm 15 \%$, and $36 \% \pm 7 \%$ of the round cells, whereas they were present in $56 \% \pm 1 \%$, $47 \% \pm 4 \%$, and $44 \% \pm 5 \%$ of the spindle-shaped cells, respectively, revealing a mild expression for both cell types (Figure 2B). Compared with myoblasts (see Supplemental Figure $\mathrm{S} 1$ at $h$ ttp://ajp.amjpathol.org), these data demonstrate that MuStem cells mainly correspond to committed muscle cells at an early stage of the myogenic lineage.

Using appropriate differentiation media, we demonstrate that MuStem cells are able to differentiate into myocytes, osteocytes, and adipocytes. After myogenic differentiation, MuStem cell-derived cultures displayed numerous multinucleated myotubes that were highly positive for the developmental isoform of $\mathrm{MyHCd}$ (Figure 3A). Osteogenic differentiation was demonstrated by the formation of multiple layers of dense cells, a large proportion of which became positive for alkaline phosphatase (ALP) and by massive calcium depositions as revealed by Alizarin Red staining (Figure 3B). After adipogenic induction, almost all cells presented extensive accumulation of small neutral lipid vesicles in their cytoplasm after staining with Oil Red O (Figure 3C).

\section{MuStem Cells Participate in Muscle Fiber Formation and Restore Dystrophin}

To determine whether MuStem cells could regenerate fibers in highly damaged muscles, $n / s$-lacZ-transduced MuStem cells were injected into skeletal muscles of a 2.5-month-old, immunosuppressed GRMD dog. As a control, n/s-lacZ-transduced myoblasts were injected into contralateral muscles. When analyzed 4 weeks later, each MuStem cell-injected muscle displayed many lac $Z^{+}$ nuclei, which dramatically contrasted with the absence of lac $Z^{+}$nuclei in the myoblast-injected muscles (Figure $4 A)$. The tissue distribution of the lac $Z^{+}$nuclei is presented in Table 2 (dog \#8). The vast majority of the nuclei $(71.6 \%)$ were found in a peripheral position, whereas the remaining ones were found either centrally located $(15.6 \%)$ or in the endomysial tissue (12.8\%) (Figure 4B). Similar results were obtained when MuStem cells were injected into the triceps brachii muscle of three 8-monthold GRMD dogs (\#9 to \#11). To precisely locate lac $Z^{+}$ nuclei with a peripheral position, double immunolabeling of dystrophin and laminin was performed on MuStem cell-injected muscle of two 2.5-month-old dogs (\#12, \#13). We determined that $71.1 \%$ had a subplasma membrane position, $12.2 \%$ were found above the basal membrane, and $16.7 \%$ were found between the plasma and 
A

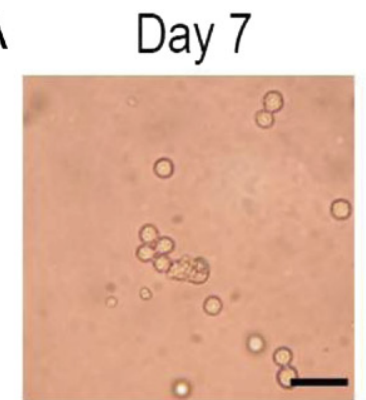

B

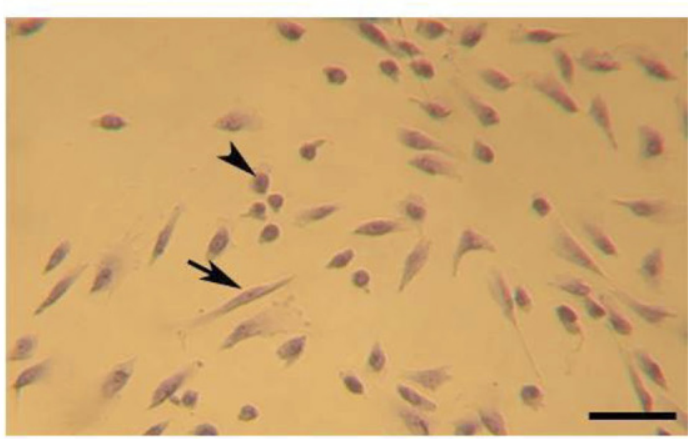

C

Non adherent condition

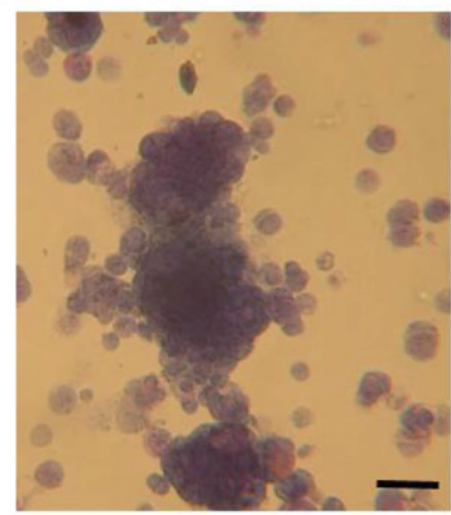

$\mathrm{D}$

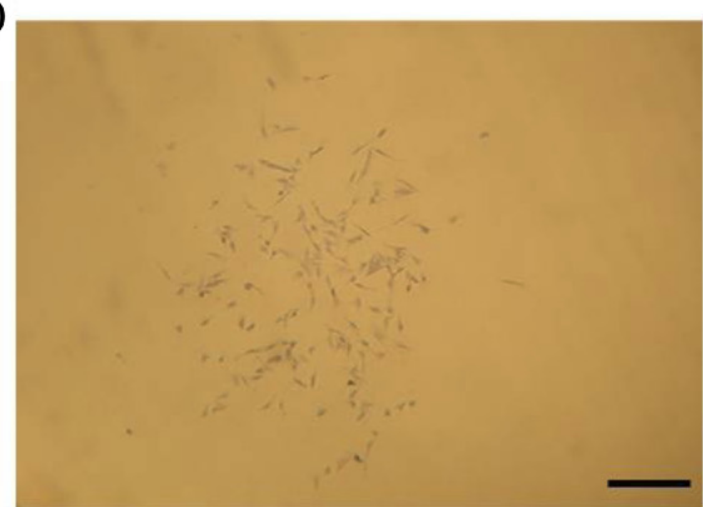

Day 10
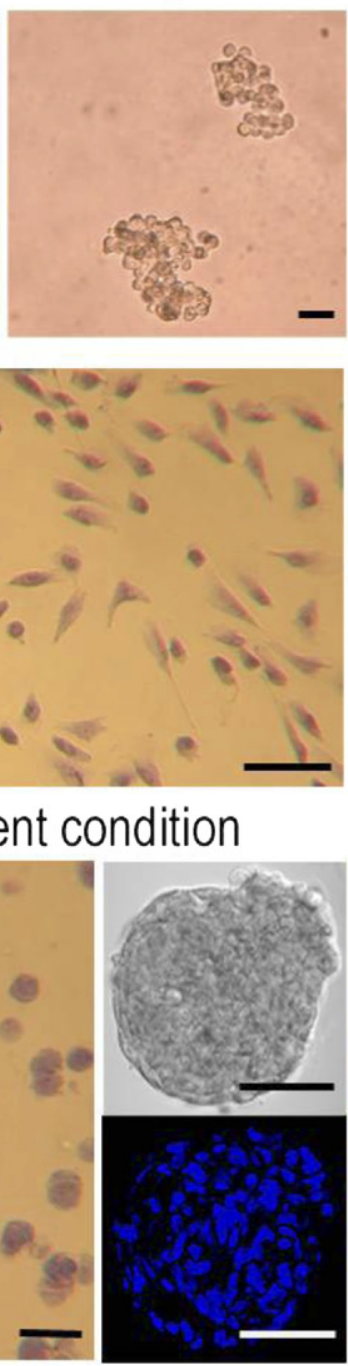

$-$
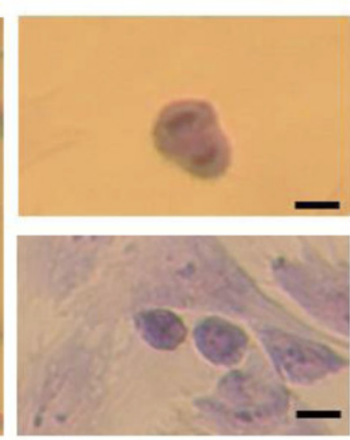

Adherent condition
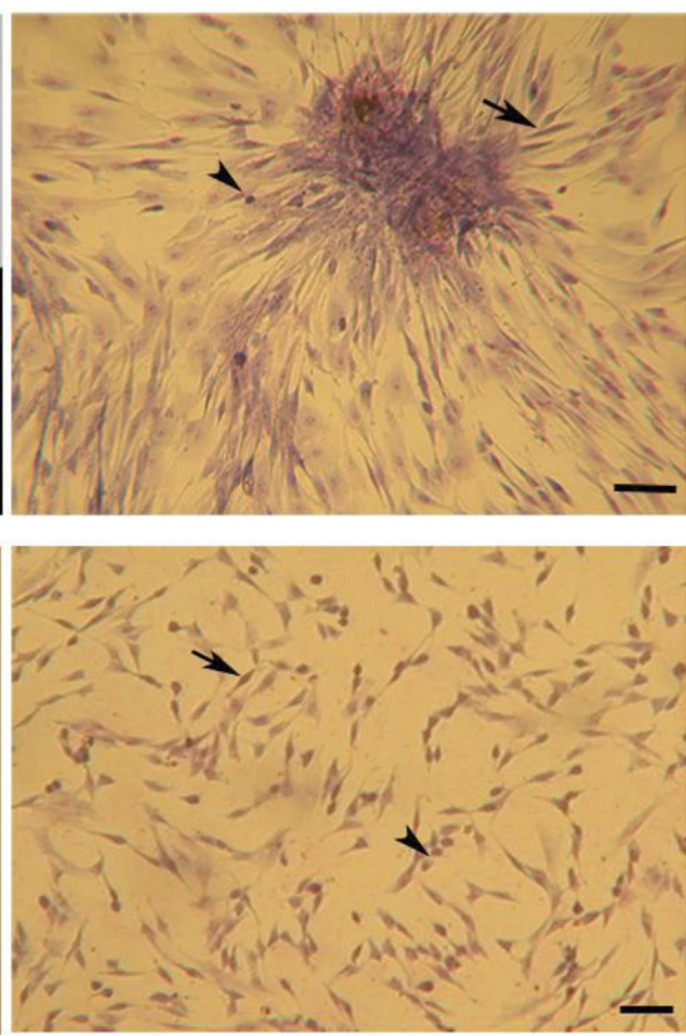

Figure 1. Growth modalities of MuStem cells. MuStem cells were isolated from muscle-derived cells after six successive platings $(n=7$, independent experiments). A: Morphological examination in phase contrast revealing progressive formation of microspheroid colonies that generated adherent spindle-shaped cells (arrow) and round cells (arrowhead). B: After several passages, cultures displayed spindle-shaped cells (arrow) and round cells (arrowhead). Right panels: The round cells divided by generating round cells and spindle-shaped ones (arrow). C: Under nonadherent conditions, MuStem cells proliferate by generating myospheres composed of hundreds of round cells. Replated on gelatin-coated matrix, myospheres gave rise to spindle-shaped cells (arrow) and poorly adherent round cells (arrowhead). D: Clonal culture of MuStem cells. Right panel: Colonies were characterized by the presence of the two morphologically distinct cell types. Scale bars: $10 \mu \mathrm{m}$ (B, right panels); $25 \mu \mathrm{m}$ (A); $50 \mu \mathrm{m}$ (B, C, and D, right panel); and $100 \mu \mathrm{m}$ (D).

the basal membrane, ie, in the satellite cell niche (Figure $4 \mathrm{C})$. Of interest is that Pax7 expression could be demonstrated for these latter nuclei, indicating that MuStem cells could acquire satellite cell identity (Figure 4D) and supplement the pool of endogeneous satellite cells in dystrophic context. To document the myogenic potential of the MuStem cells that did not fuse with host fibers (ie, those located in endomysial tissue or in satellite cell niche), n/s- 
A
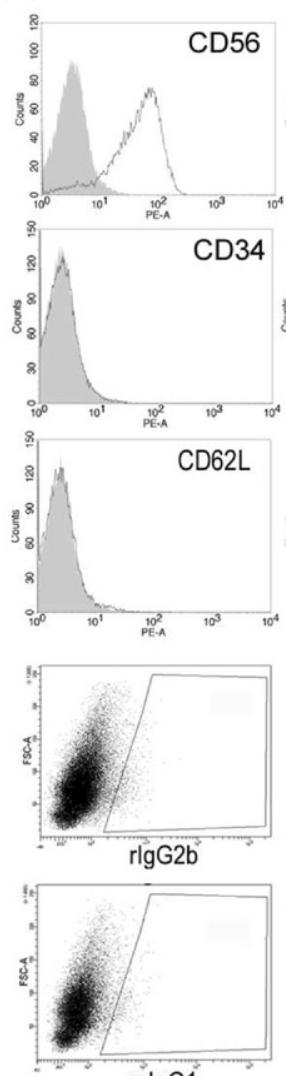

mlgG1
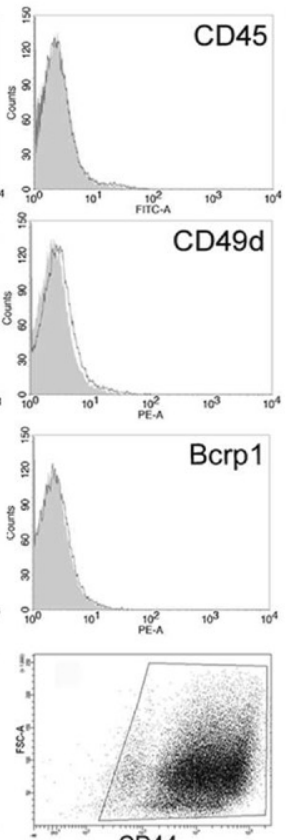

CD44

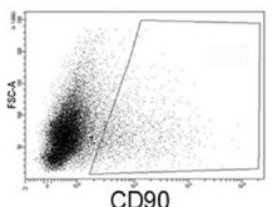

B

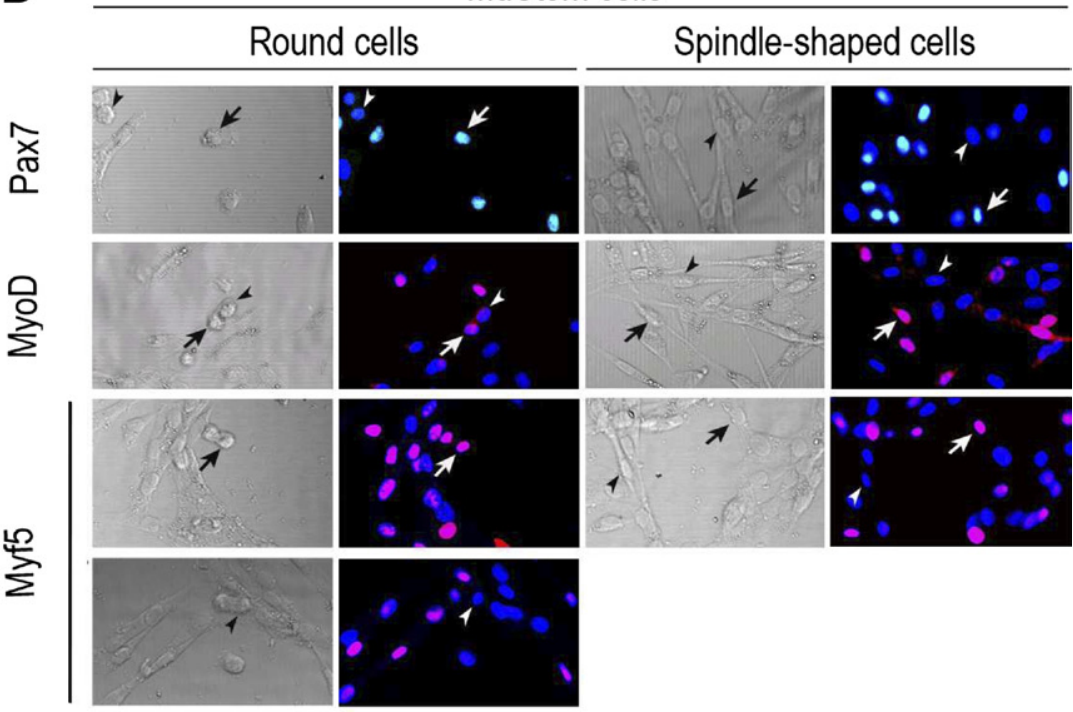

Figure 2. Phenotype of MuStem cells. A: Surface labeling for CD56, CD45, CD 34, CD 49d, CD62L, Bcrp-1, CD 44, and CD90 was determined for expanded MuStem cells $(n=4)$. Shaded areas, control immunoglobulins; black lines, specific antibodies. RIgG2b and mIgG1 corresponded to control immunoglobulins for CD44 and CD90, respectively. B: Cells were cultured on Lab-Tek chambers slides and subjected to immunolabelings for myogenic markers. Expression of Pax7, MyoD, and Myf5 by round cells and spindle-shaped cells. Arrows and arrowheads showed positive and negative cells, respectively. Scale bar $=20 \mu \mathrm{m}$.

lacZ-transduced MuStem cells were injected in the Biceps femoris muscle of two 2.5-month-old dogs (\#12, \#13). Four weeks later, mononucleated cells were isolated from the injected muscles and seeded in primary culture. As shown in Figure 4E, lac $Z^{+}$nuclei were observed in several myotubes that resulted from their fusion with non-lac $Z^{+}$nuclei, demonstrating that MuStem cells in muscle-resident positions maintain their myogenicity. Altogether, these results provide strong evidence that MuStem cells are effective in muscle fiber formation, either directly by fusing with host fibers or by generating myogenic-resident cells.

In addition, we determined that all fibers containing lac $Z^{+}$ nuclei were dystrophin ${ }^{+}$(Figure 5A) and also expressed $\gamma$-sarcoglycan ( $\gamma$-SG), $\beta$-sarcoglycan ( $\beta$-SG), and $\beta$-dystroglycan $(\beta-D G)$ throughout the fiber membrane, where they down-expressed utrophin (Figure 5B). These results establish that MuStem cells could restore the dystrophin-glycoprotein complex in GRMD dog fibers.

\section{Systemic Delivery of MuStem Cells Leads to Clinical Stabilization of GRMD Dogs}

The potential use of MuStem cells as a clinical tool for cell therapy would be reinforced if they are shown to be able to reach their muscle target following systemic delivery. To check this possibility, n/s-lacZ MuStem cells were intraarterially injected in two immunosuppressed 7-month-old GRMD dogs (\#14, \#15). Eight weeks later, several hun- dreds of lac $Z^{+}$nuclei were observed in hind limb muscles of each dog with a tissue localization similar to those observed after intramuscular injection (Table 2): $84.2 \%$ had a subbasal position, 1.9\% were centralized nuclei, and $13.9 \%$ displayed an endomysial position. This positive result prompted us to perform a more complete analysis.

Five systemic injections of $10^{7}$ wild-type MuStem cells/kg were realized on three immunosuppressed GRMD dogs (\#16 to \#18) at intervals of 2 to 4 weeks. Six untreated dogs (\#19 to \#24) displayed a progressive clinical impairment with a course distributed in three phases (Figure 6A). Before the age of 14 weeks, the dogs exhibited only few signs characteristic of muscular dystrophy, the most prominent being palmigrade/plantigrade stances (Figure 6B, inset) and increased splaying of the digits. Their clinical score remained above $70 \%$ of that obtained by the healthy dogs. Between 14 and 26 weeks, a rapid decline of their walking ability was observed with progressive weakness, abnormal stiff limbs, short strides, and marked weight transfer (Figure 6B). Meanwhile, their score decreased to less than $40 \%$ of the healthy dog score. After the age of 26 weeks, GRMD dogs showed unchanged global clinical status (see Supplemental Video S1 at http://ajp.amjpathol.org). Three mock-immunosuppressed dogs (\#19 to \#21) displayed a similar clinical course compared to the three non-immunosuppressed ones (\#22 to \#24) (Figure 6B). Importantly, the GRMD dog that had received MuStem cells earlier (dur- 
A

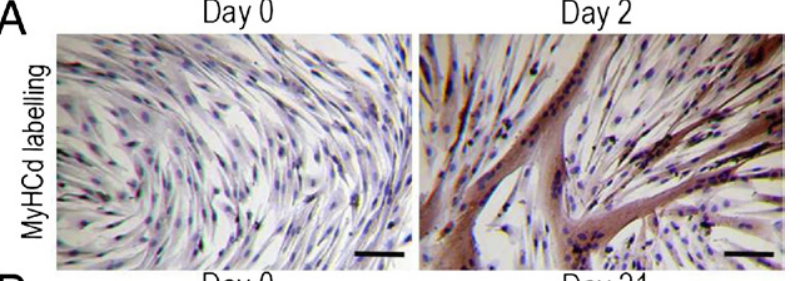

B

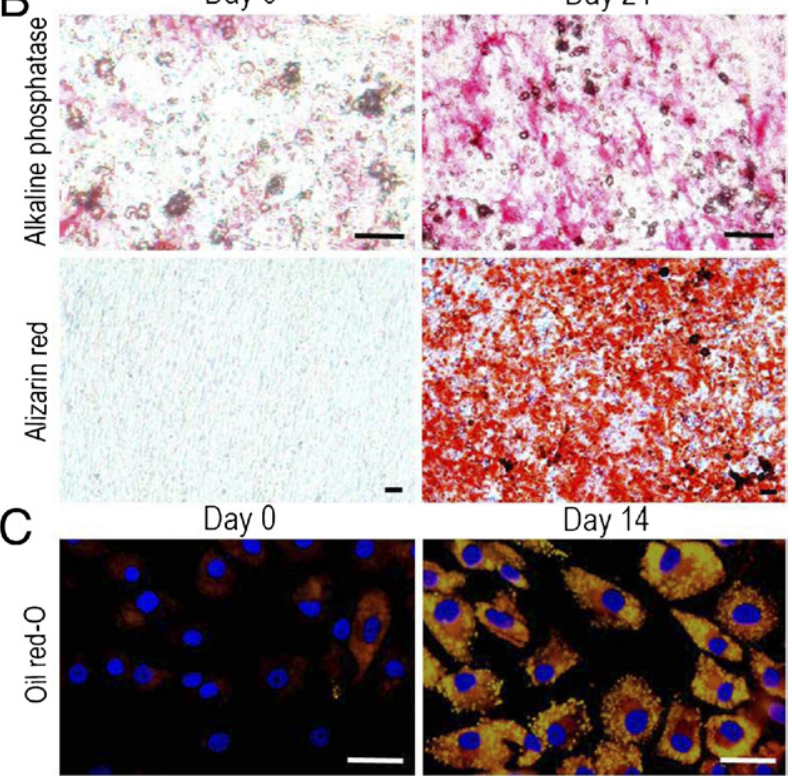

Figure 3. In vitro multilineage differentiation of MuStem cells. A: Myogenic differentiation. Before and 2 days after treatment with low serum medium, cells were labeled for MyHCd. B: Osteogenic differentiation. Before and 21 days after treatment with osteogenic medium, cells were stained with ALP and Alizarin Red for calcium deposition and mineralized nodules. C: Adipogenic differentiation. Before and 14 days after treatment with adipogenic medium, cells were stained with Oil Red O for lipid droplets $(n=2$ per group). Scale bars: $100 \mu \mathrm{m}(\mathbf{A}$ and $\mathbf{B}) ; 50 \mu \mathrm{m}(\mathbf{C})$.

ing phase 1) remained at a clinical score of about $90 \% 9$ months after the first administration (Figure 6A). The two other GRMD dogs, which were injected at the beginning of phase 2, displayed a stabilization of their scores that was maintained up to $70 \%$ of that of the healthy dogs. A statistical difference between mock-immunosuppressed GRMD dogs and MuStem cell-injected ones was determined from 17 weeks to 50 weeks of age (repeated measures analysis of variance; $P=0.014$ ). More than 6 months after the last MuStem cell injection, the three treated dogs still walked well and were active, in striking contrast with the mock-treated ones (see Supplemental Video S2 at http://ajp.amjpathol.org). The most obvious corrected criteria were the palmigrade/plantigrade stances, the weight transfer (Figure 6B), and the ease of standing up (see Supplemental Video S3 at http://ajp. amjpathol.org). One of the dogs injected in phase 2 showed a mild decrease of its score due to moderate ankylosis and limb stiffness. Creatine kinase levels did not differ between mock-immunosuppressed GRMD dogs and MuStem cell-injected ones, but depended on cyclosporinemia ( $P=0.031$, analysis of covariance), as illustrated in Supplemental Figure S2 at http://ajp. amjpathol.org, This tight correlation between creatine kinase levels and cyclosporinemia should preclude the use
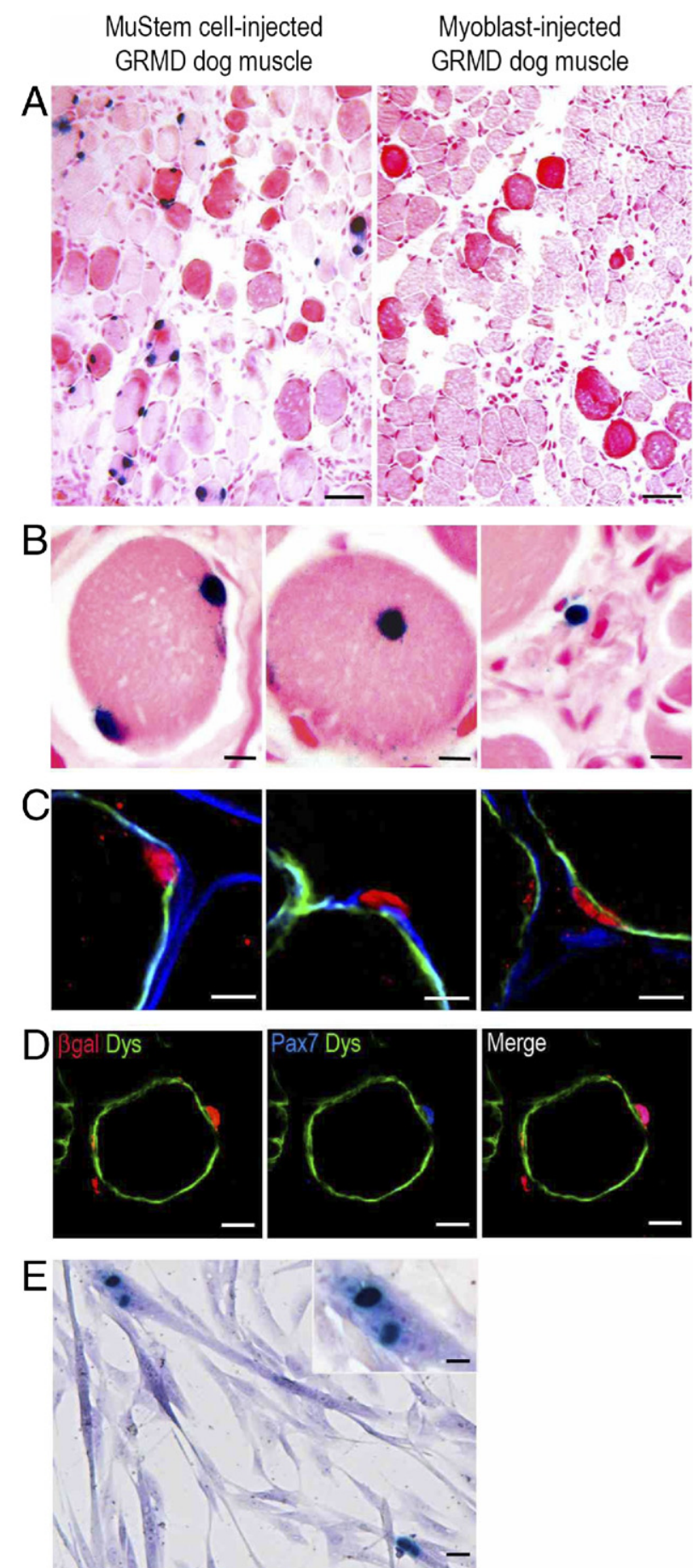

Figure 4. In vivo behavior of MuStem cells after intramuscular injection Four weeks after intramuscular injection of $n l s$-LacZ-transduced MuStem cells, muscles were biopsied and investigated. A: Kernechtrot stain of representative sections treated for $l a c Z$ expression. B: Tissue distribution analysis ( $n=6$ muscles on four dogs: \#8 to \#11) revealing different localization of $\mathrm{lac}^{+}$nuclei: peripheral (left), centronuclear (middle), or in an interstitial (right) position. C: Immunolabelings for lac $Z$ (red), plasma membrane (dystrophin ${ }^{+}$, green), and basal membrane (laminin ${ }^{+}$, blue) showing the presence of peripheral $\mathrm{lac}^{+}$nuclei below the plasma membrane of fibers (left), above the basal membrane (middle), or between both membranes (right). D: $\mathrm{LaCZ}^{+}$nuclei (left, red) located above the plasma membrane (left, dystrophin ${ }^{+}$: green), was $\mathrm{Pax}^{+}$(middle, blue); merged image (right). E: Primary culture of cells isolated from muscle previously injected with MuStem cells was assayed for lacZ expression (blue) to reveal the presence of $\mathrm{lac}^{+}$nuclei in myotubes. Scale bars: $50 \mu \mathrm{m}(\mathbf{A}) ; 10 \mu \mathrm{m}$ (B and E: inset); $20 \mu \mathrm{m}(\mathbf{C}$ and D) $25 \mu \mathrm{m}(\mathbf{E})$ 
A

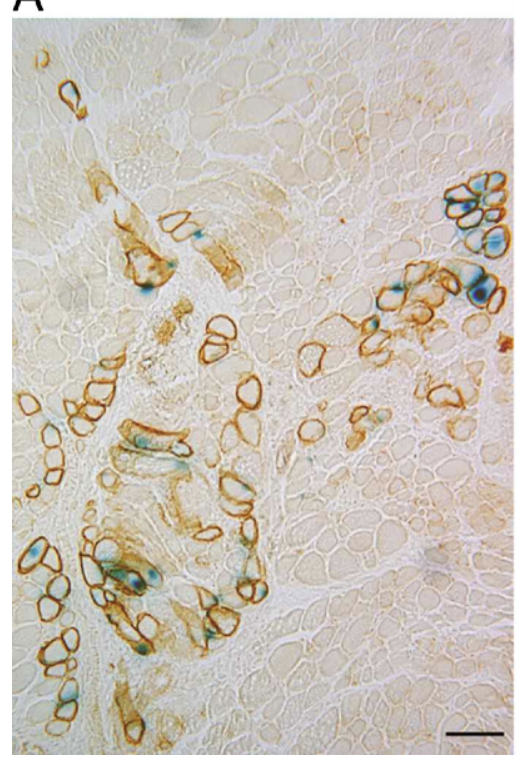

$\mathrm{B}$

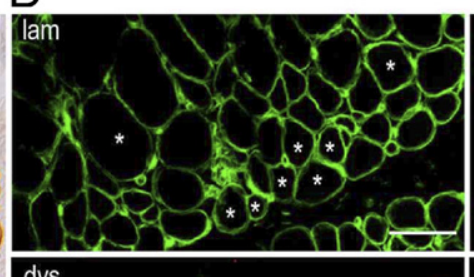

dys
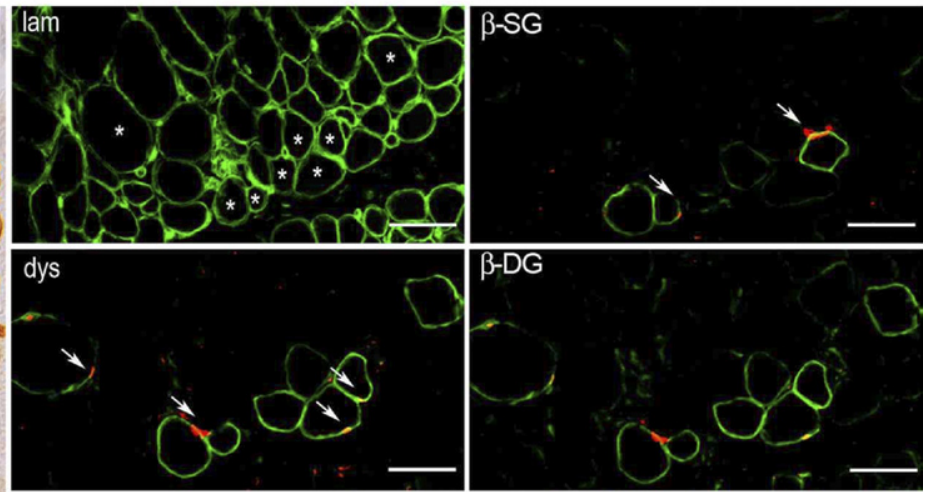

\section{$\beta-D G$}
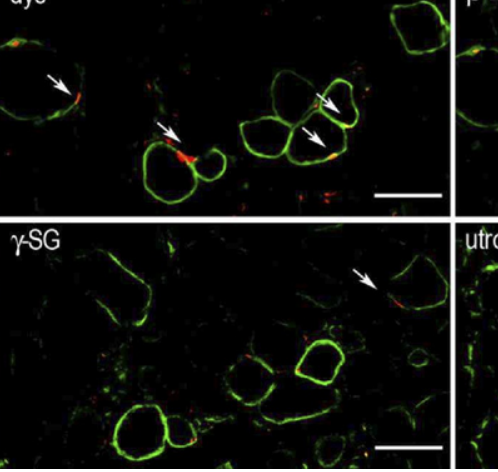

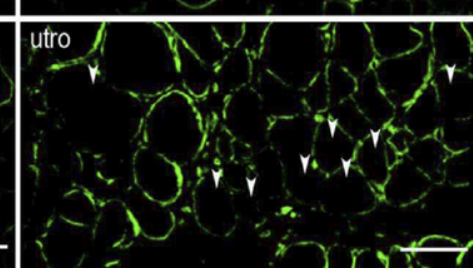

Figure 5. Dystrophin and dystrophin-associated glycoprotein expression after intramuscular injection of MuStem cells. A: Muscle sections were assayed for lac $Z$ expression (blue) and immunolabeled for dystrophin (brown), to reveal lac $Z^{+} /$dystrophin ${ }^{+}$fibers. B: In serial sections, immunolabelings for laminin (lam), lac $Z$ (red) and dystrophin (dys), $\gamma$-SG, $\beta$-SG, $\beta$-DG, utrophin (green) were performed ( $n=3$ ). Clusters of lac $Z^{+} /$dystrophin $^{+}$muscle fibers expressing the different dystrophin-associated glycoproteins were observed (asterisks). Lac $Z^{+}$nuclei (arrows) and dystrophin ${ }^{+} /$utrophin $^{-}$fibers (arrowheads) were indicated. Scale bars: $100 \mu \mathrm{m}(\mathbf{A}) ; 50 \mu \mathrm{m}(\mathbf{B})$.

of creatine kinase as a biological marker of treatment efficacy in case of immunosuppression. Aspartate aminotransferase, another enzyme released by damaged muscle fibers, showed an overall similar pattern (data not shown). Collectively, these results demonstrate that systemic delivery of MuStem cells allows global and persistent stabilization of the GRMD dog's clinical status.

\section{Systemic Delivery of MuStem Cells Allows Dystrophin Recovery in GRMD Dog Muscles}

To document dystrophin expression in muscles after systemic delivery of MuStem cells, muscle biopsies were obtained at various time points and subjected to RT-PCR analysis. One month after the first injection, wild-type
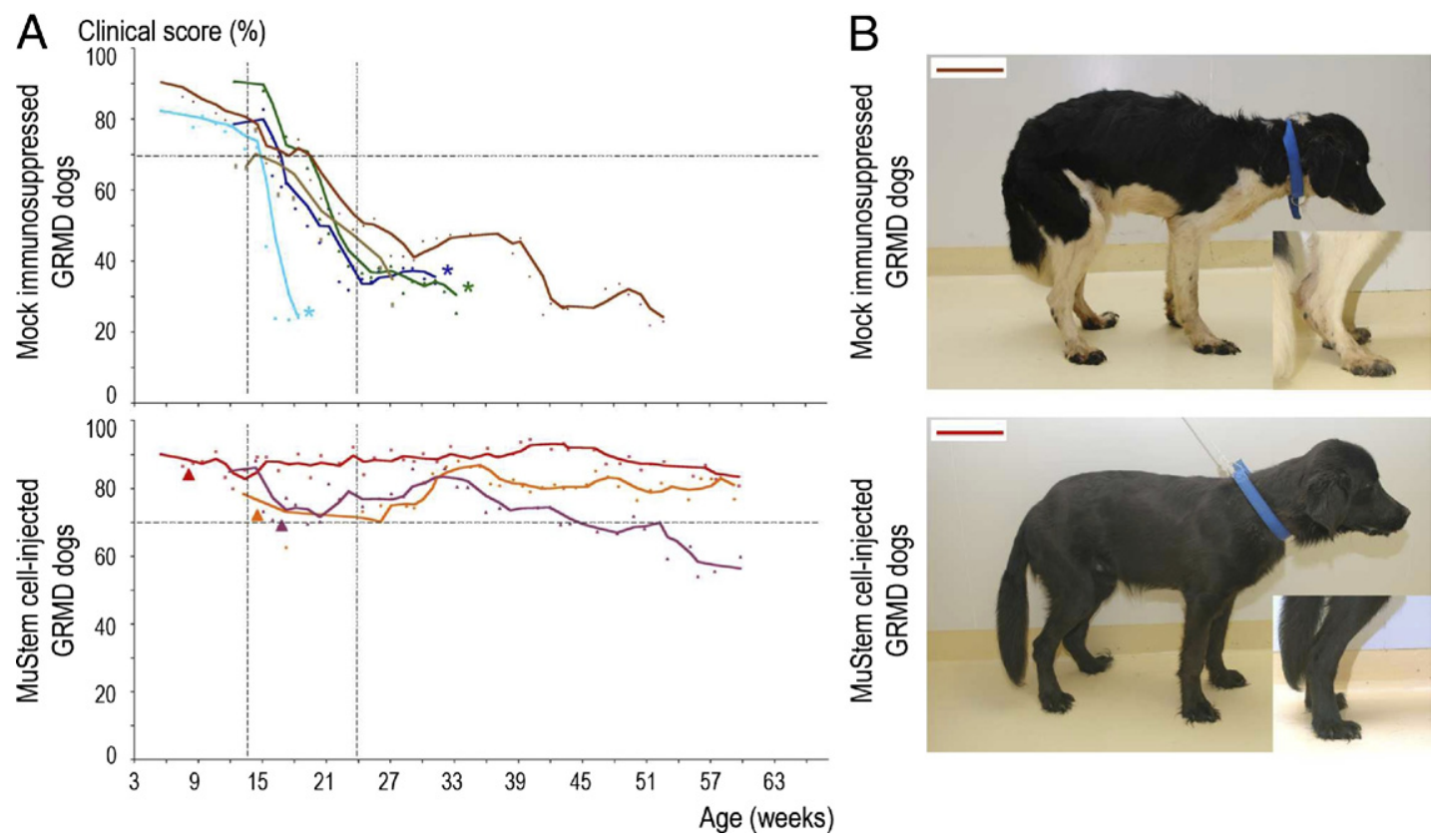

Figure 6. Clinical evaluation of GRMD dogs. The clinical score was determined weekly and expressed as a percentage of a theoretical healthy dog score. A: Clinical course of muscular dystrophy on GRMD dogs $(n=3)$, mock-immunosuppressed GRMD dog $(n=2$; brown lines), and MuStem cell-injected ones ( $n=3)$. The first cell administration (arrowheads) and the time when dogs were excluded for ethical reasons (asterisks) were noted. B: Right lateral view of a mock-treated 36-week-old GRMD dog (top, dark brown line in A). Anterior weight transfer and plantigrady (inset) were visible. Right lateral view of a treated 36-week-old GRMD dog (bottom, red line, littermate with dog presented above). Note the roughly normal posture of the animal and the straightness of the limbs (inset). 
A

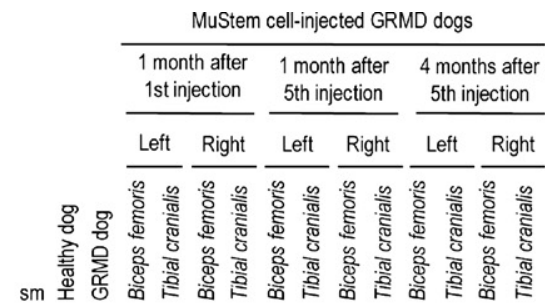

놈

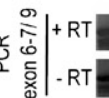

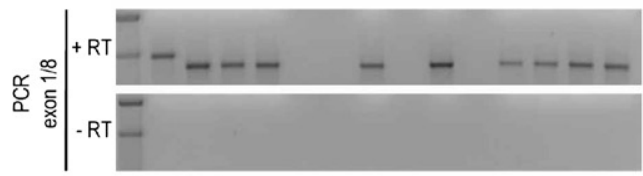

B
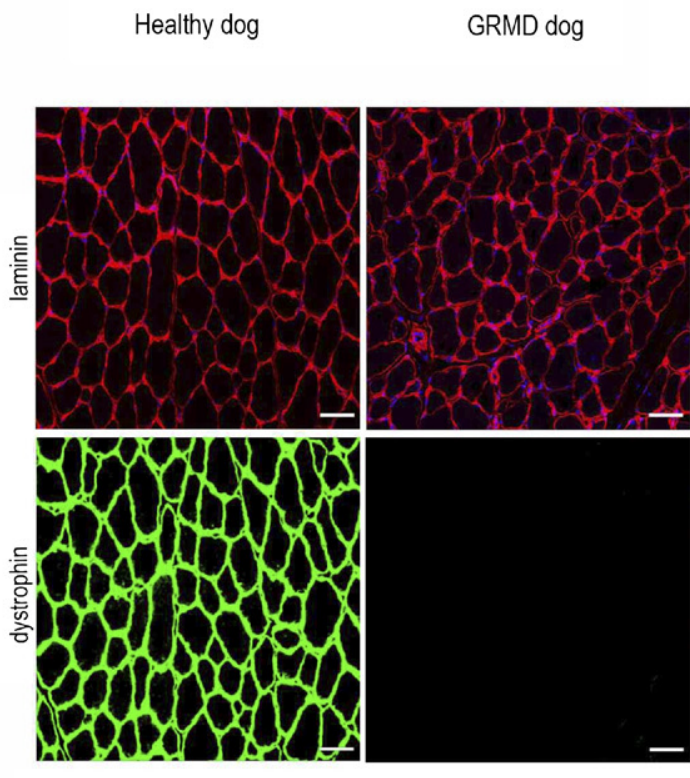

MuStem cell-injected GRMD dog 4 months after 5 th injection

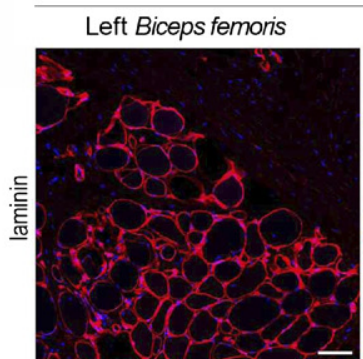

Left Tibialis cranialis
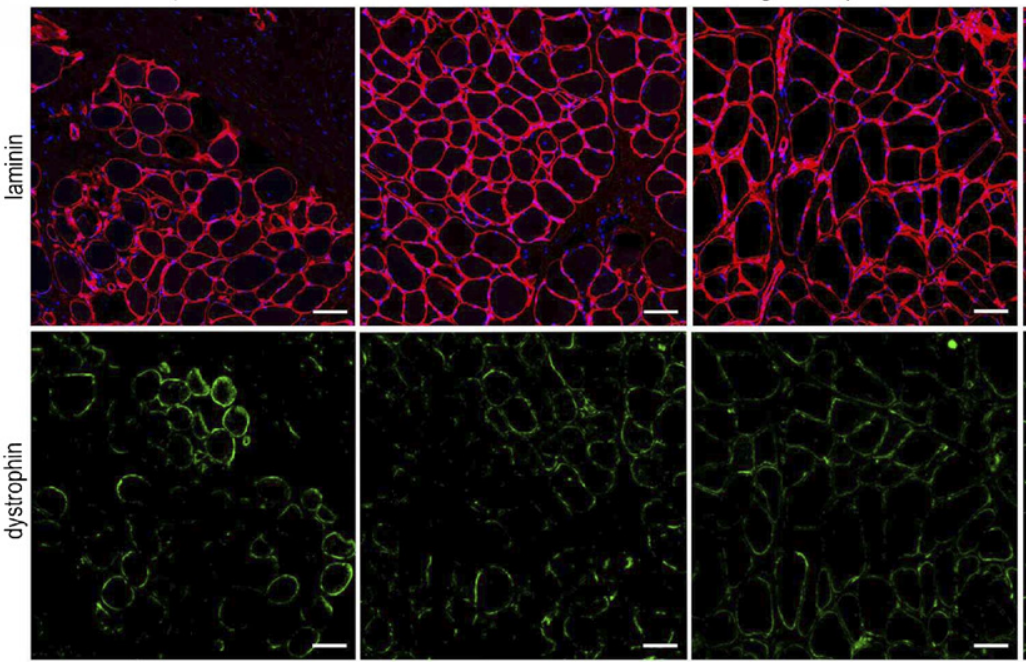

Right Biceps femoris

MuStem cell-injected GRMD dog

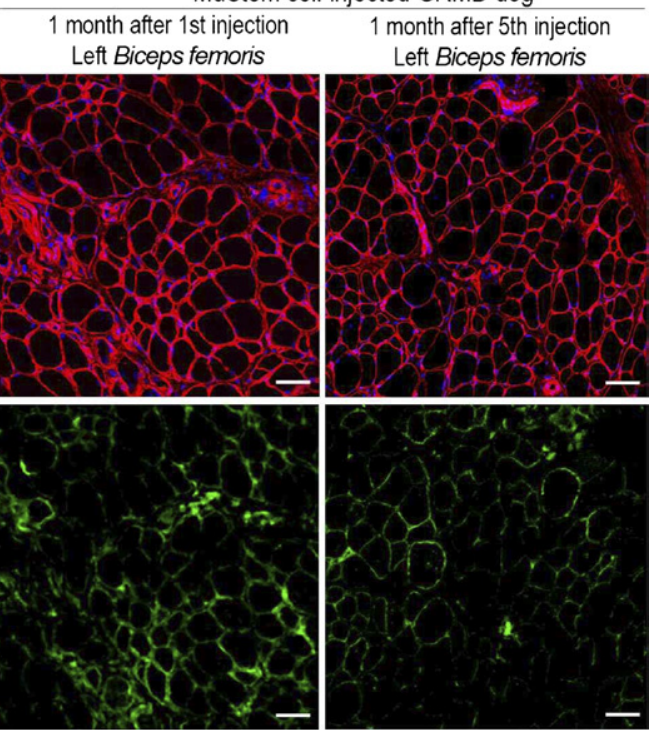

month after 5 th injection

Right Tibialis cranialis

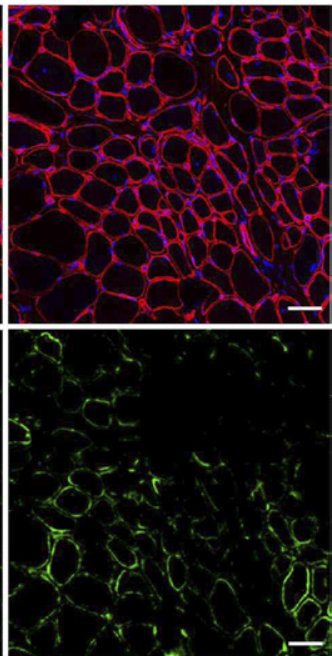

dystrophin RNA was present in skeletal muscles of the left limb, which is the side that was injected, indicating that a single injection of $10^{7}$ MuStem cells $/ \mathrm{kg}$ is sufficient to allow dystrophin synthesis in muscles downstream from the injection site (Figure 7A). One month after the last injection, dystrophin RNA was detected in the biceps femoris muscle of both limbs. More important, dystrophin RNA persisted in muscles of both limbs by 


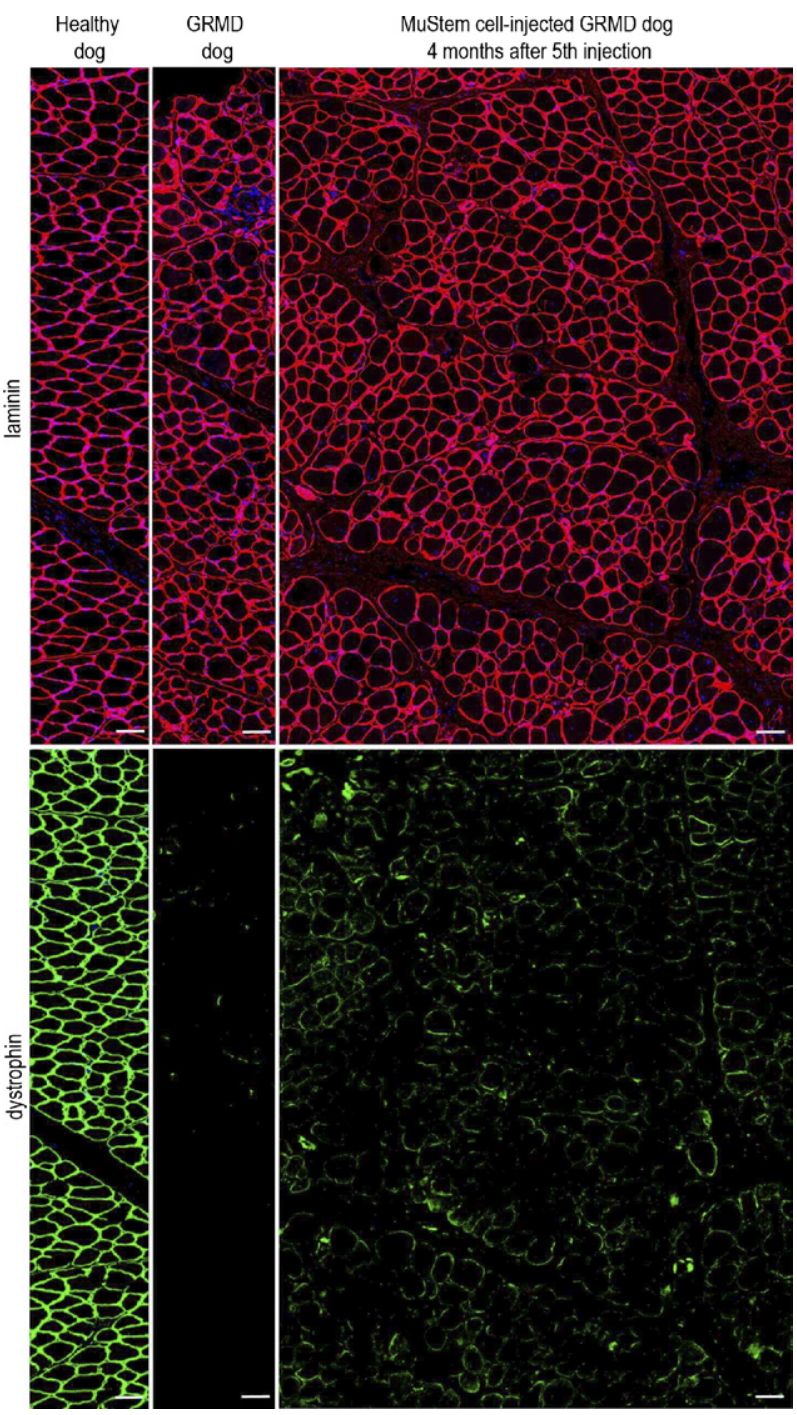

Figure 8. Dystrophin expression in GRMD dog muscle 4 months after the last MuStem cell systemic delivery. In serial muscle sections, laminin (red) and dystrophin (green) immunolabelings were done $(n=3)$. Low magnification showing scattered dystrophin ${ }^{+}$fibers over the whole section. Scale bar $=50 \mu \mathrm{m}$.

4 months after the last cell injection. In addition, a large number of muscle fibers expressing dystrophin were demonstrated in cross sections, not only of the left muscles, but also of the right muscles (Figure 7B and Figure 8). It should be noted that dystrophin expression identified isolated fibers as well as clusters of fibers and that labeling was characterized by a low level compared to that observed in healthy dog muscle. Four months after the last injection, dystrophin ${ }^{+}$ fibers ranged from $20 \%$ to $25 \%$ and $25 \%$ to $30 \%$ in the left biceps femoris and tibialis cranialis muscles of GRMD dogs, respectively, whereas "revertant" fibers represented less than $0.2 \%$ of fibers in untreated GRMD dog muscles. Western blot analysis of muscle biopsies collected on two MuStem cell-injected GRMD dogs 4 and 7 months after the last injection confirmed the presence of dystrophin in treated muscles (see Supplemental Figure S3 at http://ajp.amjpathol.org).
Even though the dystrophin expression level was much lower than that observed in healthy dog muscles, these results demonstrate that systemic delivery of MuStem cells allows an efficient homing of these cells to the muscle, resulting in long-term dystrophin expression.

\section{Systemic Delivery of MuStem Cells Acts on the Histopathological Phenotype of GRMD Dogs}

Regenerative activity of dystrophic fibers was assessed on 7-month-old dogs, using a specific labeling to the developmental MyHC isoform whose expression is restricted to development and regeneration processes. Although no $\mathrm{MyHCd}^{+}$fibers were observed in healthy dog Biceps femoris muscle $(n=3), 14.5 \% \pm 4.1 \%$ of fibers expressed this isoform in the corresponding GRMD dog muscle ( $n=3$, Figure 9A). Strikingly, the $\mathrm{MyHCd}^{+}$fiber represented $33.4 \% \pm 7.5 \%$ of the fibers in Biceps femoris muscle of treated GRMD dog more than 4 weeks after the last MuStem cell injection $(n=3)$. This higher proportion compared to that observed in mock-immunosuppressed animals $(P<0.05)$, indicates that MuStem cells actively and persistently contribute to fiber regeneration. On the basis of the minimum Ferret diameter, we showed that the mean fiber diameter was $42.4 \pm 13.8,33.4 \pm 12.9$, and $37.1 \pm 14.3 \mu \mathrm{m}$ for healthy dogs, mock-immunosuppressed GRMD dogs, and treated ones, respectively (Figure 9B). It was significantly higher in treated GRMD dogs than in mock-immunosuppressed ones $(P<0.001)$. This increased diameter was illustrated by the modal value that was 40 to $60 \mu \mathrm{m}$ in treated GRMD dog muscles $(41.5 \% \pm 2.5 \%)$, such as in healthy dog muscles $(47.8 \% \pm 6.7 \%)$, whereas it corresponded to 20 to $40 \mu \mathrm{m}$ in mock-immunosuppressed dog muscles $(52.7 \% \pm$ $10.4 \%$ ). The largest fibers (with diameter $>60 \mu \mathrm{m}$ ) represented $12.6 \% \pm 14.6 \%$ of all fibers in healthy dog muscles, whereas this percentage was lower in mockimmunosuppressed GRMD dogs $(2.0 \% \pm 1.4 \%)$ and increased after treatment in GRMD dogs (5.3\% $\pm 1.5 \%)$. Fibrosis was determined as the ratio of collagen-positive areas on the total muscle area, using collagen type I immunolabeling. No significant difference was determined between mock-immunosuppressed GRMD dogs and treated ones, probably because of the minor size of the dog group. Measuring the intercellular spaces that only considered the endomysial component of connective tissue and not both endomysial and perimysial tissues, we showed that endomysial thickness was $0.7 \pm$ $0.1,2.1 \pm 0.4$, and $1.1 \pm 0.1 \mu \mathrm{m}$ in healthy, mockimmunosuppressed GRMD dogs, and treated ones, respectively (Figure 9C). Treated GRMD dogs exhibited highly reduced endomysial space all across the sections compared to mock-immunosuppressed animals $(P<$ 0.001) (Figure 9D). Other histopathological features of GRMD dog muscles (ie, calcification, necrosis, and inflammation) were found to be unmodified (data not shown). Altogether, systemic delivery of MuStem cells generates a partial, but significant, histological correcting remodeling of the GRMD dog muscle consistent with the clinical output. 

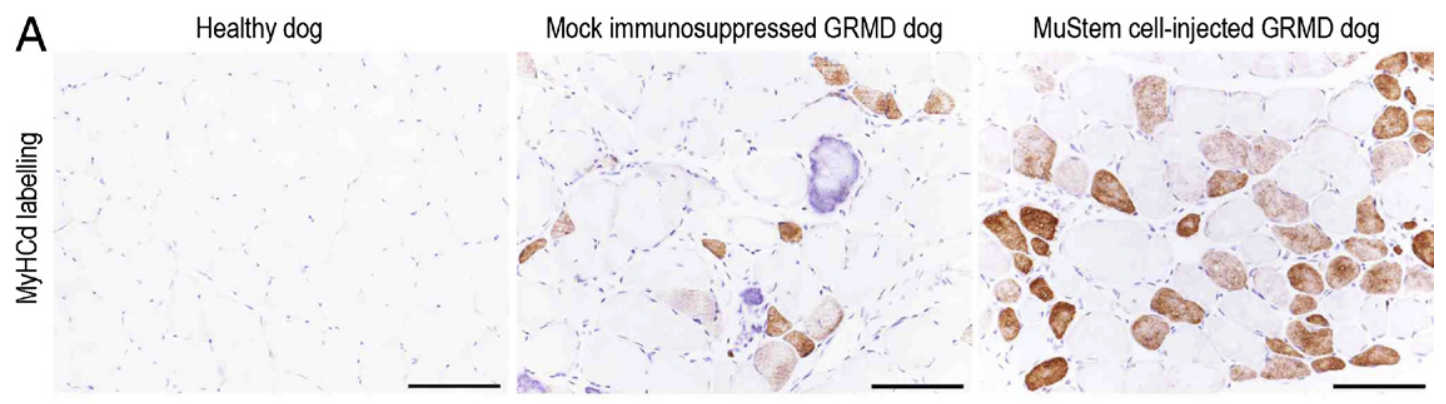

$\mathrm{B}$
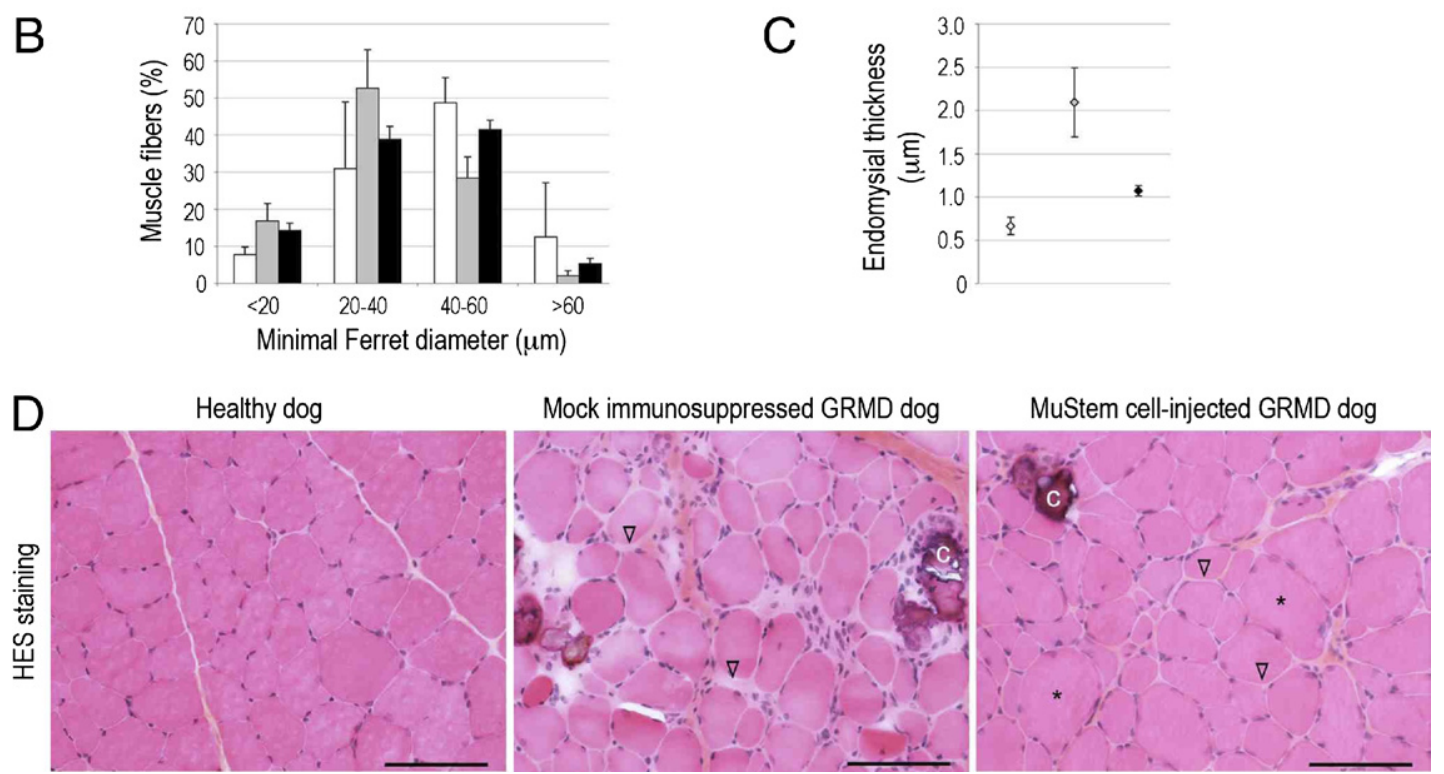

Figure 9. Histological impact of MuStem cell systemic delivery. Histomorphometric analysis of muscular elementary lesions was performed on the Biceps femoris muscle of 7-month-old healthy dogs, mock-immunosuppressed GRMD dogs, and MuStem cell-injected GRMD dogs ( $n=3$ per group), ie, more than 4 weeks after the last cell injection. A: Regenerative activity in GRMD dog muscles was assessed by MyHCd labeling (brown). B: Fiber size distribution. Healthy dogs (white bars), GRMD dogs (gray bars), and treated GRMD dogs (black bars). C: Mean endomysial thickness. D: Hematoxylin-eosin-safranin stain of representative muscle sections. Hypertrophic fibers (asterisks), fibrosis (arrowheads), and calcified fibers (c) were indicated. Scale bar $=100 \mu \mathrm{m}$.

\section{Discussion}

Different stem cell populations can be isolated from adult skeletal muscles, and it has been suggested that they could represent a promising alternative for cell-based therapy of muscular diseases based on their myogenic regeneration potential in dystrophic mice. ${ }^{62}$ In return, whether MDSC are able to have tissue and clinical impact on a clinically relevant animal model has not been investigated, except for the mesoangioblasts. ${ }^{33}$ Here, we report the reproducible isolation based on delayed adhesion properties of canine MDSC that we named MuStem cells, and demonstrate for the first time that the systemic delivery of these cells in dystrophic dogs allows dystrophin recovery, efficiently prevents muscle deterioration, and contributes to a global and persistent stabilization of the dog's clinical status.

MuStem cells were isolated as initial floating round cells after a similar procedure to the one described by Huard's group. ${ }^{30}$ Originally, we showed that MuStem cells generated a heterogeneous population composed of spindleshaped flat cells and a low percentage of round cells that remained constant due to the ability of these cells to perform atypical division pattern. Most of cells expressed sat- ellite cell markers Pax7, CD56, and $\beta 1$-integrin or myogenic regulatory factors Myf5 and MyoD, suggesting that MuStem cells could originate from satellite cell niche and corresponded mainly to early myogenic progenitors. They exhibited ex vivo multilineage differentiation potential into osteocyte and adipocyte cell lineages even though they appeared to be committed to the myogenic lineage as evidenced by their ability to spontaneously differentiate into myotubes. These features distinguished MuStem cells from mice MDSC, ${ }^{35,63}$ Mabs, $^{33,64-66}$ and SP cells ${ }^{67,68}$ that do not express key myogenic transcription factor Pax7, and/or differentiate into multinucleated myotubes only when cocultured with primary myoblasts or after transfection with MyoD. MuStem cells were able to expand in suspension, an experimental condition that does not support proliferation of differentiated cells that rapidly die. ${ }^{69}$ In this original proliferation context, MuStem cells gave rise to large clusters of rounded cells termed myospheres, which have been also described for cells freshly isolated from mice ${ }^{41}$ and human $^{70}$ skeletal muscle.

After intramuscular injection in GRMD dogs that display severe muscular dystrophy with close histological similarities to $\mathrm{DMD},{ }^{45,46}$ we detected many hundreds of 
MuStem cells in muscles, whereas no myoblast could be observed. This revealed that MuStem cells were able to survive in the DMD context after in vitro expansion in contrast to cultured myoblasts known to have an extremely poor survival rate after injection in host muscle. ${ }^{11,71,72}$ In parallel to fusion with host fibers and dystrophin recovery, MuStem cells generated satellite cells, an essential feature in the context of satellite cell pool exhaustion in muscular dystrophy. ${ }^{73,74}$ This data suggested that MuStem cell injection could have a long-term impact on the regenerative potential of dystrophic fibers by their constant recruitment for the host fiber regeneration. Similar contribution to the satellite cell pool has been demonstrated in injured mouse muscles for muscle SP cells, ${ }^{21}$ muscle-derived floating populations, ${ }^{42} \mathrm{CD} 133^{+}$ cells, ${ }^{24}$ and synovial membrane-derived mesenchymal stem cells. ${ }^{75}$ However, this is the first time that this behavioral feature is described in highly damaged muscles such as those in GRMD dogs. In addition to their participation on fiber regeneration and satellite cell formation, we observed that MuStem cells intriguingly gave rise to interstitial cells. This behavior has been recently described for a new mouse muscle-resident stem cell subpopulation located in the interstitium, the PICs. ${ }^{29}$ Indeed, these $\mathrm{PW} 1^{+} / \mathrm{Pax} 7^{-}$non-satellite cells efficiently contribute to skeletal muscle regeneration after injection in damaged mice muscle tissue as well as generating satellite cells and PICs. Following intramuscular or systemic delivery, an endothelial differentiation of the interstitial MuStem cells was never demonstrated in contrast to blood-and muscle-derived $\mathrm{CD}_{133^{+}}$cells $^{31}$ that also differ from MuStem cells on the basis of their positive expression for CD34, CD45, CD49d, and CD90. ${ }^{24,76}$

A marked clinical stabilization of GRMD dogs with a major impact on locomotion features was noticed following systemic delivery of MuStem cells. More than 6 months after the last injection, GRMD dogs were lively in contrast to the untreated ones. Similarly, intra-arterial delivery of wild-type canine Mabs generated persistent clinical amelioration of GRMD dogs. ${ }^{33}$ Additionally, since immunosuppressive drugs and anti-inflammatory agents have been extensively described to reduce the severity of muscular dystrophy ${ }^{77}$ and improve muscle function, ${ }^{78,79}$ we documented the clinical course of treated GRMD dogs in parallel to that of non-immunosuppressed but also immunosuppressed GRMD dogs to clearly show that the clinical benefit could not be attributed to the immunosuppressive regimen. Taking into account that the clinical courses are quite similar inside the mocktreated and the treated dog groups, and are also dramatically distinct between the two groups, the clinical impact determined in the treated GRMD dogs probably cannot be explained alone by the phenotypic variability known among GRMD dogs. ${ }^{80} \mathrm{~A}$ limitation of the present study still resides in the minor size of the dog group. To extrapolate the present results to prospective human trials, a more detailed functional phenotype characterization of treated GRMD dogs will be required to complete the clinical grading that corresponds to a semiquantitative approach. The gold standard methods used for clinical assessment of DMD patients, such as the 6-minute walk test, ${ }^{81}$ were shown to be difficult to set up in the canine model. ${ }^{82}$ Also, the functional quantitative methods using kinematics and accelerometry that were recently published ${ }^{82,83}$ enable the comparison of the gait between GRMD dogs and healthy ones. Further investigations will be necessary to determine whether they could represent reliable tools to assess the efficacy of MuStem cell therapy in GRMD dogs.

Systemic administration of wild-type MuStem cells promoted the formation of numerous dystrophin ${ }^{+} \mathrm{fi}_{-}$ bers scattered over the entire section of several muscles. The dystrophin expression level was lower than that observed in a wild-type muscle as well as after intramuscular injections of MuStem cells. One must keep in mind that intramuscular injections generated a high concentration of donor cells in a limited tissue area and allowed fusion of several MuStem cell with host fibers, whereas systemic delivery resulted in a much wider dispersion of donor cells. This may reflect the fact that many more cells have to be injected to obtain a higher dystrophin expression.

In parallel to the dystrophin recovery, we showed that systemic administration of MuStem cells improved the histopathological phenotype of the GRMD dog biceps femoris muscle and demonstrated for the first time that this correcting remodeling comprised a major endomysial thickness reduction and a high increase of fiber regenerative activity. In contrast to fibrosis that results from the cumulative former pathological events occurring in the muscle tissue, fiber necrosis represents a punctual event. Moreover, because the percentages of necrosis or calcium deposits were very low (comprising between $0.5 \%$ and $2.4 \%$ ) in sampled muscles, no difference between mock-treated and treated dog muscles could be demonstrated in the small groups of animals. It will be a critical issue to determine whether this tissue remodeling that appeared sufficient to induce considerable preservation of locomotion in GRMD dog results directly from MuStem cells and/or from paracrine signaling, as determined for stromal stem cells. ${ }^{84}$ Concerning the regenerative potential, $\mathrm{MyHCd}^{+}$fibers were observed several weeks after the MuStem cell administration. Interestingly, this contribution to the regenerated fibers, delayed with regard to the systemic delivery, could promote ongoing repair of dystrophic muscle. ${ }^{85}$ Recently, a marked improvement of muscle performance was measured in both respiratory and cardiac muscles of $\mathrm{mdx}$ mice following treatment with halofuginone, a collagen synthesis inhibitor that prevented fibrosis. ${ }^{86,87}$ By demonstrating the key role of fibrosis on muscle function alterations in a dystrophic context, these findings support the hypothesis that the major restriction in endomysial expansion observed in the muscles of our treated GRMD dogs might have a direct impact on their walking ability and largely contribute to their clinical stabilization.

In conclusion, our results support our proposal that MuStem cells may represent a source of cells with therapeutic potential for DMD. Additional experiments are required to validate this proposal, among which one should demonstrate the existence of a human equivalent to the canine MuStem cells and further investigate the 
spectra of muscles that can be corrected following systemic delivery of the cells.

\section{Acknowledgments}

We thank Philippe Moullier (INSERM UMR 649, Nantes, France), Jamel Chelly and Bénédicte Chazaud (Institut Cochin, INSERM U567, CNRS UMR 8104, Paris, France) for helpful discussion and improving the manuscript. We also thank the staff of the Boisbonne Center (Oniris, Nantes, France) for the handling and care of the GRMD dog colony, and François-Loïc Cosset (INSERM U758, Lyon, France) for providing the n/s-lacZ MLV retroviral vector.

\section{References}

1. Emery AE: Population frequencies of inherited neuromuscular diseases-a world survey. Neuromuscul Disord 1991, 1:19-29

2. Hoffman EP, Brown RH Jr., Kunkel LM: Dystrophin: the protein product of the Duchenne muscular dystrophy locus. Cell 1987, 51:919928

3. Bonilla E, Samitt CE, Miranda AF, Hays AP, Salviati G, DiMauro S, Kunkel LM, Hoffman EP, Rowland LP: Duchenne muscular dystrophy: deficiency of dystrophin at the muscle cell surface. Cell 1988, 54: 447-452

4. Ervasti JM, Campbell KP: Membrane organization of the dystrophinglycoprotein complex. Cell 1991, 66:1121-1131

5. Ibraghimov-Beskrovnaya O, Ervasti JM, Leveille CJ, Slaughter CA, Sernett SW, Campbell KP: Primary structure of dystrophin-associated glycoproteins linking dystrophin to the extracellular matrix. Nature 1992, 355:696-702

6. Dubowitz V: Neuromuscular disorders in childhood. Old dogmas, new concepts. Arch Dis Child 1975, 50:335-346

7. Seale P, Sabourin LA, Girgis-Gabardo A, Mansouri A, Gruss P, Rudnicki MA: Pax7 is required for the specification of myogenic satellite cells. Cell 2000, 102:777-786

8. Morgan JE, Hoffman EP, Partridge TA: Normal myogenic cells from newborn mice restore normal histology to degenerating muscles of the mdx mouse. J Cell Biol 1990, 111:2437-2449

9. Huard J, Bouchard JP, Roy R, Malouin F, Dansereau G, Labrecque C, Albert N, Richards CL, Lemieux B, Tremblay JP: Human myoblast transplantation: preliminary results of 4 cases. Muscle Nerve 1992, 15:550-560

10. Karpati G, Holland P, Worton RG: Myoblast transfer in DMD: problems in the interpretation of efficiency. Muscle Nerve 1992, 15:12091210

11. Fan Y, Maley M, Beilharz M, Grounds M: Rapid death of injected myoblasts in myoblast transfer therapy. Muscle Nerve 1996, 19:853860

12. Beauchamp JR, Pagel CN, Partridge TA: A dual-marker system for quantitative studies of myoblast transplantation in the mouse. Transplantation 1997, 63:1794-1797

13. Morgan JE, Pagel CN, Sherratt T, Partridge TA: Long-term persistence and migration of myogenic cells injected into pre-irradiated muscles of mdx mice. J Neurol Sci 1993, 115:191-200

14. Skuk D, Roy B, Goulet M, Tremblay JP: Successful myoblast transplantation in primates depends on appropriate cell delivery and induction of regeneration in the host muscle. Exp Neurol 1999, 155: 22-30

15. Guerette B, Asselin I, Skuk D, Entman M, Tremblay JP: Control of inflammatory damage by anti-LFA-1: increase success of myoblast transplantation. Cell Transplant 1997, 6:101-107

16. Guerette B, Skuk D, Celestin F, Huard C, Tardif F, Asselin I, Roy B, Goulet M, Roy R, Entman M, Tremblay JP: Prevention by anti-LFA-1 of acute myoblast death following transplantation. J Immunol 1997, 159:2522-2531

17. Collins CA, Olsen I, Zammit PS, Heslop L, Petrie A, Partridge TA, Morgan JE: Stem cell function, self-renewal, and behavioral hetero- geneity of cells from the adult muscle satellite cell niche. Cell 2005 122:289-301

18. Cerletti M, Jurga S, Witczak CA, Hirshman MF, Shadrach JL, Goodyear LJ, Wagers AJ: Highly efficient, functional engraftment of skeletal muscle stem cells in dystrophic muscles. Cell 2008, 134:37-47

19. Montarras D, Morgan J, Collins C, Relaix F, Zaffran S, Cumano A, Partridge $\mathrm{T}$, Buckingham $\mathrm{M}$ : Direct isolation of satellite cells for skeletal muscle regeneration. Science 2005, 309:2064-2067

20. Sacco A, Doyonnas R, Kraft P, Vitorovic S, Blau HM: Self-renewal and expansion of single transplanted muscle stem cells. Nature 2008, 456:502-506

21. Gussoni E, Soneoka Y, Strickland CD, Buzney EA, Khan MK, Flint AF, Kunkel LM, Mulligan RC: Dystrophin expression in the mdx mouse restored by stem cell transplantation. Nature 1999, 401:390-394

22. Jackson KA, Mi T, Goodell MA: Hematopoietic potential of stem cells isolated from murine skeletal muscle. Proc Natl Acad Sci U S A 1999, 96:14482-14486

23. Tanaka KK, Hall JK, Troy AA, Cornelison DD, Majka SM, Olwin BB: Syndecan-4-expressing muscle progenitor cells in the SP engraft as satellite cells during muscle regeneration. Cell Stem Cell 2009, 4:217-225

24. Torrente Y, Belicchi M, Sampaolesi M, Pisati F, Meregalli M, D’Antona G, Tonlorenzi R, Porretti L, Gavina M, Mamchaoui K, Pellegrino MA, Furling D, Mouly V, Butler-Browne GS, Bottinelli R, Cossu G, Bresolin $\mathrm{N}$ : Human circulating $\mathrm{AC} 133(+)$ stem cells restore dystrophin expression and ameliorate function in dystrophic skeletal muscle. J Clin Invest 2004, 114:182-195

25. Minasi MG, Riminucci $M$, De Angelis $L$, Borello $U$, Berarducci $B$, Innocenzi A, Caprioli A, Sirabella D, Baiocchi M, De Maria R, Boratto R, Jaffredo T, Broccoli V, Bianco P, Cossu G: The meso-angioblast: a multipotent, self-renewing cell that originates from the dorsal aorta and differentiates into most mesodermal tissues. Development 2002 , 129:2773-2783

26. Rodriguez AM, Pisani D, Dechesne CA, Turc-Carel C, Kurzenne JY, Wdziekonski B, Villageois A, Bagnis C, Breittmayer JP, Groux H, Ailhaud G, Dani C: Transplantation of a multipotent cell population from human adipose tissue induces dystrophin expression in the immunocompetent mdx mouse. J Exp Med 2005, 201:1397-1405

27. Pittenger MF, Mackay AM, Beck SC, Jaiswal RK, Douglas R, Mosca JD, Moorman MA, Simonetti DW, Craig S, Marshak DR: Multilineage potential of adult human mesenchymal stem cells. Science 1999, 284:143-147

28. Goudenege S, Pisani DF, Wdziekonski B, Di Santo JP, Bagnis C, Dani C, Dechesne CA: Enhancement of myogenic and muscle repair capacities of human adipose-derived stem cells with forced expression of MyoD. Mol Ther 2009, 17:1064-1072

29. Mitchell KJ, Pannerec A, Cadot B, Parlakian A, Besson V, Gomes ER, Marazzi G, Sassoon DA: Identification and characterization of a nonsatellite cell muscle resident progenitor during postnatal development. Nat Cell Biol 2010, 12:257-266

30. Qu Z, Balkir L, van Deutekom JC, Robbins PD, Pruchnic R, Huard J: Development of approaches to improve cell survival in myoblast transfer therapy. J Cell Biol 1998, 142:1257-1267

31. Benchaouir R, Meregalli M, Farini A, D'Antona G, Belicchi M, Goyenvalle A, Battistelli M, Bresolin N, Bottinelli R, Garcia L, Torrente Y: Restoration of human dystrophin following transplantation of exonskipping-engineered DMD patient stem cells into dystrophic mice. Cell Stem Cell 2007, 1:646-657

32. Sampaolesi M, Torrente $Y$, Innocenzi A, Tonlorenzi R, D'Antona G, Pellegrino MA, Barresi R, Bresolin N, De Angelis MG, Campbell KP, Bottinelli R, Cossu G: Cell therapy of alpha-sarcoglycan null dystrophic mice through intra-arterial delivery of mesoangioblasts. Science 2003, 301:487-492

33. Sampaolesi M, Blot S, D'Antona G, Granger N, Tonlorenzi R, Innocenzi A, Mognol P, Thibaud JL, Galvez BG, Barthelemy I, Perani L, Mantero S, Guttinger M, Pansarasa O, Rinaldi C, Cusella De Angelis MG, Torrente Y, Bordignon C, Bottinelli R, Cossu G: Mesoangioblast stem cells ameliorate muscle function in dystrophic dogs. Nature 2006, 444:574-579

34. Jankowski RJ, Haluszczak C, Trucco M, Huard J: Flow cytometric characterization of myogenic cell populations obtained via the preplate technique: potential for rapid isolation of muscle-derived stem cells. Hum Gene Ther 2001, 12:619-628 
35. Qu-Petersen Z, Deasy B, Jankowski R, Ikezawa M, Cummins J, Pruchnic R, Mytinger J, Cao B, Gates C, Wernig A, Huard J: Identification of a novel population of muscle stem cells in mice: potential for muscle regeneration. J Cell Biol 2002, 157:851-864

36. Oshima H, Payne TR, Urish KL, Sakai T, Ling Y, Gharaibeh B, Tobita $\mathrm{K}$, Keller BB, Cummins JH, Huard J: Differential myocardial infarct repair with muscle stem cells compared to myoblasts. Mol Ther 2005, 12:1130-1141

37. Lee JY, Qu-Petersen Z, Cao B, Kimura S, Jankowski R, Cummins J, Usas A, Gates C, Robbins P, Wernig A, Huard J: Clonal isolation of muscle-derived cells capable of enhancing muscle regeneration and bone healing. J Cell Biol 2000, 150:1085-1100

38. Cao B, Zheng B, Jankowski RJ, Kimura S, Ikezawa M, Deasy B, Cummins J, Epperly M, Qu-Petersen Z, Huard J: Muscle stem cells differentiate into haematopoietic lineages but retain myogenic potential. Nat Cell Biol 2003, 5:640-646

39. Torrente Y, Tremblay JP, Pisati F, Belicchi M, Rossi B, Sironi M, Fortunato F, El Fahime M, D'Angelo MG, Caron NJ, Constantin G, Paulin D, Scarlato G, Bresolin N: Intraarterial injection of musclederived CD34(+)Sca-1(+) stem cells restores dystrophin in $\mathrm{mdx}$ mice. J Cell Biol 2001, 152:335-348

40. Torrente Y, Camirand G, Pisati F, Belicchi M, Rossi B, Colombo F, El Fahime M, Caron NJ, Issekutz AC, Constantin G, Tremblay JP, Bresolin $\mathrm{N}$ : Identification of a putative pathway for the muscle homing of stem cells in a muscular dystrophy model. J Cell Biol 2003, 162:511520

41. Sarig R, Baruchi Z, Fuchs O, Nudel U, Yaffe D: Regeneration and transdifferentiation potential of muscle-derived stem cells propagated as myospheres. Stem Cells 2006, 24:1769-1778

42. Arsic N, Mamaeva D, Lamb NJ, Fernandez A: Muscle-derived stem cells isolated as non-adherent population give rise to cardiac, skeletal muscle and neural lineages. Exp Cell Res 2008, 314:1266-1280

43. Bulfield G, Siller WG, Wight PA, Moore KJ: X chromosome-linked muscular dystrophy (mdx) in the mouse. Proc Natl Acad Sci U S A 1984, 81:1189-1192

44. Anderson JE, Bressler $\mathrm{BH}$, Ovalle WK: Functional regeneration in the hindlimb skeletal muscle of the mdx mouse. J Muscle Res Cell Motil 1988, 9:499-515

45. Valentine BA, Cooper BJ, de Lahunta A, O'Quinn R, Blue JT: Canine X-linked muscular dystrophy. An animal model of Duchenne muscular dystrophy: clinical studies. J Neurol Sci 1988, 88:69-81

46. Shelton GD, Engvall E: Canine and feline models of human inherited muscle diseases. Neuromuscul Disord 2005, 15:127-138

47. Cooper BJ, Winand $\mathrm{NJ}$, Stedman H, Valentine BA, Hoffman EP, Kunkel LM, Scott MO, Fischbeck KH, Kornegay JN, Avery RJ, et al: The homologue of the Duchenne locus is defective in X-linked muscular dystrophy of dogs. Nature 1988, 334:154-156

48. Sharp NJ, Kornegay JN, Van Camp SD, Herbstreith MH, Secore SL, Kettle S, Hung WY, Constantinou CD, Dykstra MJ, Roses AD, et al: An error in dystrophin mRNA processing in golden retriever muscular dystrophy, an animal homologue of Duchenne muscular dystrophy. Genomics 1992, 13:115-121

49. Kornegay JN, Tuler SM, Miller DM, Levesque DC: Muscular dystrophy in a litter of golden retriever dogs. Muscle Nerve 1988, 11:1056-1064

50. Honeyman K, Carville KS, Howell JM, Fletcher S, Wilton SD: Development of a snapback method of single-strand conformation polymorphism analysis for genotyping Golden Retrievers for the X-linked muscular dystrophy allele. Am J Vet Res 1999, 60:734-737

51. Marelli D, Desrosiers C, el-Alfy M, Kao RL, Chiu RC: Cell transplantation for myocardial repair: an experimental approach. Cell Transplant 1992, 1:383-390

52. Chiu RC, Zibaitis A, Kao RL: Cellular cardiomyoplasty: myocardial regeneration with satellite cell implantation. Ann Thorac Surg 1995, 60:12-18

53. Edom F, Mouly V, Barbet JP, Fiszman MY, Butler-Browne GS: Clones of human satellite cells can express in vitro both fast and slow myosin heavy chains. Dev Biol 1994, 164:219-229

54. Delorme B, Charbord P: Culture and characterization of human bone marrow mesenchymal stem cells. Methods Mol Med 2007, 140:67-81

55. Rouger K, Brault M, Daval N, Leroux I, Guigand L, Lesoeur J, Fernandez B, Cherel Y: Muscle satellite cell heterogeneity: in vitro and in vivo evidences for populations that fuse differently. Cell Tissue Res 2004, 317:319-326
56. Kinoshita I, Huard J, Tremblay JP: Utilization of myoblasts from transgenic mice to evaluate the efficacy of myoblast transplantation. Muscle Nerve 1994, 17:975-980

57. Fletcher S, Ly T, Duff RM, Howell McC J, Wilton SD: Cryptic splicing involving the splice site mutation in the canine model of Duchenne muscular dystrophy. Neuromuscul Disord 2001, 11:239-243

58. Desguerre I, Mayer M, Leturcq F, Barbet J-P, Gherardi RK, Christov C: Endomysial fibrosis in Duchenne muscular dystrophy: a marker of poor outcome associated with macrophage alternative activation. J Neuropathol Exp Neurol 2009, 68:762-773

59. Cluchague N, Moreau C, Rocher C, Pottier S, Leray G, Cherel Y, Le Rumeur E: beta-Dystroglycan can be revealed in microsomes from mdx mouse muscle by detergent treatment. FEBS Lett 2004, 572 216-220

60. Thibaud JL, Monnet A, Bertoldi D, Barthelemy I, Blot S, Carlier PG: Characterization of dystrophic muscle in golden retriever muscular dystrophy dogs by nuclear magnetic resonance imaging. Neuromuscul Disord 2007, 17:575-584

61. Cordazzo M-C:[Development of Tools for the Clinical Evaluation of Dogs Suffering from Muscular Dystrophy] (doctoral thesis). [MaisonsAlfort, France]: École Nationale Vétérinaire d'Alfort

62. Farini A, Razini P, Erratico S, Torrente Y, Meregalli M: Cell based therapy for duchenne muscular dystrophy. J Cell Physiol 2009, 221 526-534

63. Deasy BM, Gharaibeh BM, Pollett JB, Jones MM, Lucas MA, Kanda Y, Huard J: Long-term self-renewal of postnatal muscle-derived stem cells. Mol Biol Cell 2005, 16:3323-3333

64. Cossu G, Bianco P: Mesoangioblasts: vascular progenitors for extravascular mesodermal tissues. Curr Opin Genet Dev 2003, 13:537542

65. Dellavalle A, Sampaolesi M, Tonlorenzi R, Tagliafico E, Sacchetti B, Perani L, Innocenzi A, Galvez BG, Messina G, Morosetti R, Li S, Belicchi M, Peretti G, Chamberlain JS, Wright WE, Torrente Y, Ferrari S, Bianco P, Cossu G: Pericytes of human skeletal muscle are myogenic precursors distinct from satellite cells. Nat Cell Biol 2007 , 9:255-267

66. Morosetti R, Mirabella M, Gliubizzi C, Broccolini A, De Angelis L, Tagliafico E, Sampaolesi M, Gidaro T, Papacci M, Roncaglia E, Rutella S, Ferrari S, Tonali PA, Ricci E, Cossu G: MyoD expression restores defective myogenic differentiation of human mesoangioblasts from inclusion-body myositis muscle. Proc Natl Acad Sci U S A 2006, 103:16995-17000

67. Asakura A, Seale P, Girgis-Gabardo A, Rudnicki MA: Myogenic specification of side population cells in skeletal muscle. J Cell Biol 2002, 159:123-134

68. Asakura A, Rudnicki MA: Side population cells from diverse adult tissues are capable of in vitro hematopoietic differentiation. Exp Hematol 2002, 30:1339-1345

69. Galli R, Gritti A, Bonfanti L, Vescovi AL: Neural stem cells: an overview. Circ Res 2003, 92:598-608

70. Wei Y, Li Y, Chen C, Stoelzel K, Kaufmann AM, Albers AE: Human skeletal muscle-derived stem cells retain stem cell properties after expansion in myosphere culture. Exp Cell Res 2011

71. Ito H, Vilquin JT, Skuk D, Roy B, Goulet M, Lille S, Dugre FJ, Asselin I, Roy R, Fardeau M, Tremblay JP: Myoblast transplantation in nondystrophic dog. Neuromuscul Disord 1998, 8:95-110

72. Beauchamp JR, Morgan JE, Pagel CN, Partridge TA: Dynamics of myoblast transplantation reveal a discrete minority of precursors with stem cell-like properties as the myogenic source. J Cell Biol 1999, 144:1113-1122

73. Heslop L, Morgan JE, Partridge TA: Evidence for a myogenic stem cell that is exhausted in dystrophic muscle. J Cell Sci 2000, 113(Pt 12):2299-2308

74. Endesfelder S, Krahn A, Kreuzer KA, Lass U, Schmidt CA, Jahrmarkt C, von Moers A, Speer A: Elevated p21 mRNA level in skeletal muscle of DMD patients and $\mathrm{mdx}$ mice indicates either an exhausted satellite cell pool or a higher p21 expression in dystrophin-deficient cells per se. J Mol Med 2000, 78:569-574

75. De Bari C, Dell'Accio F, Vandenabeele F, Vermeesch JR, Raymackers JM, Luyten FP: Skeletal muscle repair by adult human mesenchymal stem cells from synovial membrane. J Cell Biol 2003, 160:909918

76. Gavina M, Belicchi M, Rossi B, Ottoboni L, Colombo F, Meregalli M, Battistelli M, Forzenigo L, Biondetti P, Pisati F, Parolini D, Farini A, 
Issekutz AC, Bresolin N, Rustichelli F, Constantin G, Torrente Y: VCAM-1 expression on dystrophic muscle vessels has a critical role in the recruitment of human blood-derived CD133+ stem cells after intra-arterial transplantation. Blood 2006, 108:2857-2866

77. Radley HG, De Luca A, Lynch GS, Grounds MD: Duchenne muscular dystrophy: focus on pharmaceutical and nutritional interventions. Int J Biochem Cell Biol 2007, 39:469-477

78. Miller RG, Sharma KR, Pavlath GK, Gussoni E, Mynhier M, Lanctot AM, Greco CM, Steinman L, Blau HM: Myoblast implantation in Duchenne muscular dystrophy: the San Francisco study. Muscle Nerve 1997, 20:469-478

79. De Luca A, Nico B, Liantonio A, Didonna MP, Fraysse B, Pierno S, Burdi R, Mangieri D, Rolland JF, Camerino C, Zallone A, Confalonieri P, Andreetta F, Arnoldi E, Courdier-Fruh I, Magyar JP, Frigeri A, Pisoni M, Svelto M, Conte Camerino D: A multidisciplinary evaluation of the effectiveness of cyclosporine a in dystrophic mdx mice. Am J Pathol 2005, 166:477-489

80. Ambrosio CE, Fadel L, Gaiad TP, Martins DS, Araujo KP, Zucconi E, Brolio MP, Giglio RF, Morini AC, Jazedje T, Froes TR, Feitosa ML, Valadares MC, Beltrao-Braga PC, Meirelles FV, Miglino MA: Identification of three distinguishable phenotypes in golden retriever muscular dystrophy. Genet Mol Res 2009, 8:389-396

81. Mercuri E, Mayhew A, Muntoni F, et al; TREAT-NMD Neuromuscular Network: Towards harmonisation of outcome measures for DMD and SMA within TREAT-NMD; report of three expert workshops: TREATNMD/ENMC workshop on outcome measures, 12th-13th May 2007. Naarden, The Netherlands; TREAT-NMD workshop on outcome mea- sures in experimental trials for DMD, 30th June-1st July 2007, Naarden, The Netherlands; conjoint Institute of Myology TREAT-NMD meeting on physical activity monitoring in neuromuscular disorders, 11th July 2007, Paris, France. Neuromuscul Disord 2008, 18:894-903

82. Barthelemy I, Barrey E, Thibaud JL, Uriarte A, Voit T, Blot S, Hogrel JY: Gait analysis using accelerometry in dystrophin-deficient dogs. Neuromuscul Disord 2009, 19:788-796

83. Marsh AP, Eggebeen JD, Kornegay JN, Markert CD, Childers MK: Kinematics of gait in golden retriever muscular dystrophy. Neuromuscul Disord 2010, 20:16-20

84. Kinnaird T, Stabile E, Burnett MS, Lee CW, Barr S, Fuchs S, Epstein SE: Marrow-derived stromal cells express genes encoding a broad spectrum of arteriogenic cytokines and promote in vitro and in vivo arteriogenesis through paracrine mechanisms. Circ Res 2004, 94: 678-685

85. Berry SE, Liu J, Chaney EJ, Kaufman SJ: Multipotential mesoangioblast stem cell therapy in the $\mathrm{mdx} / \mathrm{utrn}-\mathrm{-}$ - mouse model for Duchenne muscular dystrophy. Regen Med 2007, 2:275-288

86. Turgeman T, Hagai Y, Huebner K, Jassal DS, Anderson JE, Genin O, Nagler A, Halevy O, Pines M: Prevention of muscle fibrosis and improvement in muscle performance in the $\mathrm{mdx}$ mouse by halofuginone. Neuromuscul Disord 2008, 18:857-868

87. Huebner KD, Jassal DS, Halevy O, Pines M, Anderson JE: Functional resolution of fibrosis in $\mathrm{mdx}$ mouse dystrophic heart and skeletal muscle by halofuginone. Am J Physiol Heart Circ Physiol 2008, 294: H1550-1561 